\title{
O papel do órgão regulador na resolução de disputas entre operadoras de telecomunicações: a arbitragem e a mediação à luz das experiências japonesa, inglesa e americana
}

The regulatory agency's role regarding resolution of disputes in the telecommunication sector: understanding arbitration and mediation through Japanese, British and American experiences

Artur Coimbra de Oliveira*

\section{Resumo}

A função jurisdicional do órgão regulador brasileiro é ainda pouco debatida, em parte pelo fato de a Lei Geral de Telecomunicações não ter aberto possibilidades novas e significativas para a atuação da Administração Pública nesse sentido. $\mathrm{O}$ artigo analisa como órgãos reguladores estrangeiros exercem a função de dirimir conflitos entre operadoras de telecomunicações e, particularmente, como são usadas a arbitragem e a mediação para isso. A partir desse estudo, analisam-se criticamente os meios que a ANATEL possui para atuar na resolução dessas disputas, formulando-se sugestões para que esse papel do órgão regulador nacional possa ser aprimorado.

\section{Abstract}

Discussions about the adjudicatory function of the Brazilian telecommunication regulatory agency (ANATEL) are still underrated, in part because the 1997 General Telecommunications Law did not create new and significant tools for the regulator to play that role. This article investigates how foreign regulators tackle disputes between telecommunication companies, focusing on how arbitration and mediation are used for that purpose. It also analyzes ANATEL's possibilities of acting on such resolution of disputes processes, and proposes how the national regulator might improve this function.

"Membro do Grupo de Estudos em Direito das Telecomunicações e do Grupo de Pesquisa e Trabalho em Arbitragem, Mediação e Negociação da Faculdade de Direito da Universidade de Brasília. Mestrando em Direito, Estado e Constituição na Universidade de Brasília. Procurador Federal. Assessor na Secretaria de Assuntos Estratégicos da Presidência da República. 


\section{Introdução}

A liberalização de mercados para a prestação de serviços de telecomunicações em âmbito mundial a partir da última década do século $\mathrm{XX}$ demandou a criação de órgãos reguladores do setor que buscassem resguardar o interesse público em meio a atuação dos entes privados. $\mathrm{O}$ Brasil procedeu à criação da Agência Nacional de Telecomunicações (ANATEL), que é um órgão autônomo cujo dever é regulamentar e fiscalizar o setor fundando-se em dois princípios de atuação: a universalização dos serviços básicos de telecomunicações e a ampla e justa concorrência na exploração de serviços.

Entre os encargos oriundos do dever de garantir a competição, está o papel de resolver os conflitos entre operadoras. ${ }^{1} \mathrm{O}$ papel do regulador é muito importante nesse sentido, principalmente quando se trata da necessidade de regulação concorrencial assimétrica, em que as operadoras já estabelecidas gozam de alto poder de mercado em virtude de possuírem a maior parte das redes de telecomunicações.

Tais disputas entre prestadoras podem ser um forte empecilho competitivo, especialmente se têm por trás uma prática anticoncorrencial de uma operadora com poder de mercado contra uma empresa entrante. É normal que, pela lógica de mercado e empresarial, as operadoras tentem preservar ao máximo seu poder monopolístico e isso se dá, não raras vezes, por negativas de se possibilitar interconexão de redes a outra prestadora, por recusas em se permitir o unbundling, por práticas tarifárias desleais, entre outras formas. ${ }^{2}$ Dessa maneira, o papel da Agência em dirimir as disputas referentes a esses casos é um meio de se garantir a justa competição no mercado.

Outros fatores que contribuem para a Agência assumir a resolução de disputas entre operadoras de telecomunicações são a falta de preparo técnico do Poder Judiciário e a sua incapacidade de fornecer respostas rápidas a problemas que não podem se estender por anos sem serem definitivamente solucionados. A falta de preparo técnico é decorrente da própria organização

${ }^{1}$ BRASIL. Ministério das Comunicações. Exposição de Motivos n. 231/MC (Lei Geral de Telecomunicações), de 10 de dezembro de 1996.

${ }^{2}$ TODOROV, Francisco Ribeiro. Concorrência em telecomunicações. Brasília, 2003. Manuscrito.

Revista de Direito, Estado e Telecomunicações, v. 1, n. 1, p. 111-159 (2009)

DOI: https://doi.org/10.26512/lstr.v1i1.21740 
do Poder Judiciário, cuja divisão por competência material ainda não chegou ao ponto de alcançar um ramo específico para telecomunicações. A importância de respostas rápidas aos problemas decorre de uma questão sociológica: o tempo do sistema da economia é muito mais rápido que o do sistema do direito ${ }^{3}$ e a regulação é uma intervenção do direito na economia, necessitando muitas vezes acompanhá-la em sua velocidade para que seja eficaz.

Vários países que adotaram a liberalização do mercado de serviços de telecomunicações e implantaram órgãos reguladores autônomos decidiram por lhe atribuir também essa competência de resolver eventuais disputas entre operadoras de telecomunicações. No entanto, cada país seguiu uma linha própria para a institucionalização desse papel. O que há de comum entre todas essas formas parece ser a busca de uma proteção efetiva da concorrência.

Alguns países procuraram trazer a resolução de disputas $(\mathrm{RD})^{4}$ para o âmbito dos órgãos reguladores ampliando as hipóteses de sua atuação. Outros o fizeram restringindo ao máximo esses casos. Certos países adotaram formas de resolução de disputas tradicionalmente bem assentadas

${ }^{3}$ Lê-se em Luhmann: "Gracias a la diferenciación funcional, los sistemas quedan puestos en libertad para que autodeterminen sus condiciones y sus estructuras. Esto quiere decir que se construyen tiempos especificamente propios de los sistemas. (...) Estas diferencias se hacen notar, sobre todo, ahí donde la comunicación está expresada en forma de organizaciones. Pero aun las organizaciones, a veces, se ven rebasadas por las sucesiones temporales drásticas: la rapidez con la que la economía reacciona a los cambios de los precios con cambio de precios, contrasta de manera muy especial con la lentitud con la que la ciencia presenta los resultados de las investigaciones deseadas - ámbito éste en el que predomina más bien la orientación a largo plazo y a la sorpresa; es decir: a lo posterior". E, complementando: "Para ganar tiempo (y con el tiempo, futuro, y con éste, incertidumbre), el sistema jurídico instituye procesos. El sistema opera en forma del encadenamiento de acontecimientos individuales, constituyendo así un tiempo propio que se puede sincronizar más o menos con los tiempos del entorno". (LUHMANN, Niklas. El derecho de la sociedad. Tradução de Javier Torres Nafarrate. México, 1999. Manuscrito, p. 305 e 151).

${ }^{4} \mathrm{O}$ termo resolução de disputas (RD) é usado em substituição a resolução alternativa de disputas (RAD), porém com o mesmo significado. São as formas existentes de se resolver disputas fora do Poder Judiciário. Essa mudança terminológica é uma diretriz do GT Arbitragem, que considera a busca ao Poder Judiciário, sim, uma forma alternativa de resolução das disputas. 
e tecnicamente ricas. Alguns outros países articularam essa competência do órgão regulador por meio de meros processos administrativos de decisão.

Quão vasta é a experiência na resolução de disputas em órgãos reguladores de diferentes países? Como se apresentam, quais as opções e qual o procedimento para essa resolução de disputas por autoridades reguladoras estrangeiras? Que concepções sobre o que é um órgão regulador e sobre o próprio Estado subjazem a cada método? Este artigo busca ampliar a visão que se possui das opções que um órgão regulador tem para resolver as disputas entre operadoras de telecomunicações. Adota-se como marco uma observação de como cada país lida com a relação entre o órgão regulador de um lado e a mediação e a arbitragem de outro. Para isso, podem-se pinçar três países com tradições bem distintas nesse campo: Japão, Inglaterra e Estados Unidos. A partir do estudo de cada um desses modelos, propõe-se uma comparação e uma reflexão sobre as alternativas que a ANATEL possui para aprimorar o cumprimento desse dever.

\section{Os métodos de resolução de disputas}

Para os objetivos deste artigo, foram selecionadas duas formas de RDs, consideradas as que possuem técnica e tradição mais sólidas, sendo, assim, também largamente utilizadas no mundo: a arbitragem e a mediação. São métodos de natureza distinta, na medida em que, como se verá, o primeiro é heterocompositivo e o segundo, autocompositivo. Todavia, ambos têm em comum a ideia de aproximar mais as partes do resultado, conferindo-lhe maior legitimidade, e de se abrirem alternativas de decisão além dos jogos de soma zero ${ }^{5}$ proporcionados pelo processo judicial.

${ }^{5}$ Esse é um termo próprio da teoria dos jogos, que é aplicada ao estudo das diferentes formas de resolução de disputas. "Jogos de soma zero são aqueles em que há dois jogadores cujos interesses são totalmente opostos. Estes jogos são aqueles nos quais o ganho de um jogador significa sempre a derrota do outro". (NASAR, Sylvia. Apud ALMEIDA, Fábio Portela Lopes de. A teoria dos jogos: uma fundamentação teórica dos métodos de resolução de disputa. In: AZEVEDO, André Gomma de (org.). Estudos em Arbitragem, Mediação e Negociação. Vol. 2. Brasília: Grupos de Pesquisa, 2003, p. 175).

Revista de Direito, Estado e Telecomunicações, v. 1, n. 1, p. 111-159 (2009)

DOI: https://doi.org/10.26512/lstr.vli1.21740 


\section{Arbitragem}

A arbitragem é o método de resolução de disputas mais conhecido e utilizado, à exceção do processo judicial. A arbitragem no Brasil é regida pela Lei n. 9.307, de 23 de setembro de 1996. É um instituto eminentemente de direito privado que visa à resolução de "(...) litígios relativos a direitos patrimoniais disponíveis" ", em que as partes submetem-se à decisão de um terceiro, chamado árbitro, ou de terceiros, assim chamados em conjunto de tribunal arbitral ou turma (ou painel, em algumas traduções) de árbitros.

Para que ocorra a arbitragem em um determinado conflito, as partes têm de possuir plena autonomia de vontade, isto é, capacidade para contratar. A escolha da arbitragem como meio de solução de controvérsias é, em regra, facultativa e o compromisso arbitral tem o condão de afastar a jurisdição estatal, não cabendo ao Poder Judiciário qualquer recurso revisional de mérito. $^{7} \mathrm{Na}$ estipulação de contratos, as partes podem incluir cláusula compromissória, que também tem esse poder, prevendo que as disputas oriundas das relações estabelecidas contratualmente devam ser dirimidas por meio de arbitragem.

O princípio da autonomia da vontade, de fato, permeia toda a concepção da arbitragem. Dessa forma, a Lei da Arbitragem brasileira é mínima ao regulamentar o procedimento arbitral, estabelecendo apenas os seus requisitos básicos, como os itens obrigatórios da sentença arbitral, também chamada de laudo arbitral, o respeito aos princípios do contraditório, da igualdade das partes, da imparcialidade do árbitro e de seu livre convencimento, hipóteses de nulidade da sentença arbitral etc. A competência para se construir o procedimento é das próprias partes. ${ }^{8}$ Elas

${ }^{6}$ BRASIL. Lei n. 9.307, de 23 de setembro de 1996, art. $1^{\circ}$.

7"A sentença proferida não fica sujeita a qualquer recurso. Nada impede, porém, que as partes estabeleçam que a sentença arbitral possa ser submetida a reexame por outro órgão arbitral ou por outros árbitros, ou ainda que, na hipótese de não ser a decisão unânime, possa o vencido interpor recurso semelhante aos embargos infringentes previstos no Código de Processo Civil (...). Importa ressaltar, porém, que tais recursos são sempre internos, nunca dirigidos a órgãos da justiça estatal". (CARMONA, Carlos Alberto. Arbitragem e processo: um comentário à Lei $\mathrm{n}$. 9.307/96. 2. ed. rev., atual. e ampl. São Paulo: Atlas, 2004, p. 44).

${ }^{8}$ BRASIL. Lei n. 9.307, de 23 de setembro de 1996. Dispõe sobre a arbitragem. Art. 21. 
também têm a opção de, concordando, vincularem-se ao procedimento préestabelecido de uma instituição. Chama-se isso de arbitragem institucional.

Apesar de a submissão a um tribunal arbitral ser geralmente fruto da vontade das partes - ambas devem entrar em acordo quanto a isso -, o uso da arbitragem é, às vezes, determinado por política regulatória ou simplesmente pela lei. É o que ocorre no ambiente de regulação das telecomunicações em vários países. Assim, tanto as autoridades regulatórias podem ingressar em um procedimento arbitral como parte, como podem ser árbitras de disputas relacionadas à sua competência. ${ }^{9}$

Vários motivos concorrem para a escolha da arbitragem como método de resolução de disputas. A arbitragem é um meio dotado de maior privacidade do que o processo judicial, que é de natureza pública. Em questões envolvendo atividade empresarial, isso é crucial, pois dificilmente uma das partes exporá todos os pontos negociais necessários à resolução da disputa em um processo aberto à vista de seus concorrentes.

As partes têm autonomia para escolher o(s) árbitro(s). Essa capacidade dá-lhes uma maior confiança na imparcialidade do árbitro para decidir a questão, legitimando mais, dessa forma, o resultado. Esse poder de escolha do(s) árbitro(s), por sua vez, fornece às partes o poder e a benesse de se escolherem pessoas especialistas nas questões ou nos temas envolvidos na disputa. ${ }^{10}$

A flexibilidade do procedimento é outro fator que atrai as partes a se utilizarem da arbitragem. Respeitados os requisitos legais ou institucionais obrigatórios, o procedimento é totalmente flexível, podendo-se convencionar desde o número de reuniões a serem realizadas até restringir a

${ }^{9}$ BRUCE, Robert R. [et alii]. Dispute Resolution in the Telecommunications Sector: Current Practices and Future Directions. Genebra: União Internacional de Telecomunicações/Banco Mundial, 2003. [on line] Disponível na Internet via WWW. URL: http://www.itu.int/ITUD/treg/Events/Seminars/2003/GSR/Documents/DRS_Final_GSR_5.pdf (Consultado em 30.06.2006), p. 23.

${ }^{10}$ Várias grandes instituições de arbitragem possuem árbitros especializados em matérias diferentes, exatamente para propiciar uma decisão de maior qualidade e uma maior satisfação das partes com o resultado. É o caso, p. ex., da World Intellectual Property Organization (WIPO) Arbitration and Mediation Center, da American Arbitration Association e da Câmara de Mediação e Arbitragem de São Paulo.

Revista de Direito, Estado e Telecomunicações, v. 1, n. 1, p. 111-159 (2009)

DOI: https://doi.org/10.26512/lstr.v1i1.21740 
autonomia decisória do(s) árbitro(s) ${ }^{11}$ e decidir se será possível recurso após a decisão. ${ }^{12}$ Outrossim, o tempo que se leva para alcançar uma decisão no procedimento arbitral é consideravelmente menor em relação ao tempo que se leva para conseguir uma decisão definitiva no processo judicial.

Por fim, ressalta-se mais um aspecto em prol da arbitragem: a continuidade do bom relacionamento entre as partes disputantes. Por meio da arbitragem, a probabilidade de elas manterem uma relação amigável entre si após o processo é maior do que no Judiciário, que tem um processo orientado para o total confronto entre os pólos processuais. Essa vantagem é um bem muito valorizado em setores como o de telecomunicações, que funciona com base em uma forte interdependência entre os agentes econômicos.

\section{Mediação}

A mediação, no Brasil, não possui qualquer regulamentação legal. ${ }^{13}$ Trata-se de uma forma de resolução de disputas em que as próprias partes chegam a um resultado consensual. Distingue-se da pura negociação pelo fato de ter a presença de um terceiro imparcial (mediador). A função do mediador pode variar conforme a técnica utilizada por ele, mas, basicamente, consiste em facilitar a comunicação entre as partes, identificando os interesses subjacentes ao discurso de cada uma delas. $\mathrm{O}$ mediador ajuda as partes a enxergarem além da superfície conflituosa e alcançarem acordos mutuamente recompensáveis. Como são as partes que definem a decisão, a importância de sua autonomia na escolha do

${ }^{11}$ Tem-se, como exemplo dessa restrição à liberdade decisória do árbitro, o método da arbitragem delimitada (bracketed arbitration), em que se impõem limites negociados pelas partes.

${ }^{12}$ Apesar da possibilidade de se convencionar a possibilidade de recursos, Carmona sustenta que isso é deveras incomum.

${ }^{13}$ Há, em trâmite no Congresso Nacional, projeto de lei que visa a regulamentar a atividade de mediação paraprocessual no País (P.L. n. 4.827/1998). Apesar de não haver lei regulando a mediação no Brasil, destacam-se projetos-piloto na aplicação da mediação, tanto no campo cível quanto no criminal, encampados pelo TJDFT e pelo TJBA. 
mediador ${ }^{14}$ e na opção por participar do procedimento é ainda maior que na arbitragem. ${ }^{15}$

Durante o processo de mediação, o mediador deve sempre se atentar para evitar que uma parte imponha-se à outra por meio de forças externas ao processo de mediação, tais como a autoridade, a força física, a intimidação etc. O processo de mediação é ainda mais flexível do que o processo de arbitragem, todavia ainda possuindo uma base mínima a ser seguida. ${ }^{16}$ Essa maior maleabilidade do processo dá-se, em boa parte, porque não há uma necessidade procedimental de se chegar a uma decisão. Se as partes entrarem em consenso, decidem; se não, inexiste imposição de um resultado pelo mediador ou por outro terceiro.

A postura do mediador na intervenção entre as partes pode revelar aspectos técnicos que oscilam de uma prática avaliadora para uma prática facilitadora, podendo, ainda, trazer em si uma carga transformadora. $\mathrm{Na}$ mediação facilitadora - ou não-avaliadora ou não-diretiva -, o mediador não emite qualquer opinião sobre as questões em disputa, preocupando-se apenas em filtrar a comunicação entre as partes de sorte a aproximar seus interesses e, assim, contribuindo a que elas convirjam a um resultado considerado justo por ambas. Na mediação avaliadora - ou diretiva -, o mediador, além de facilitar a comunicação entre as partes, também opina sobre questões de fato e de direito, mas não decide. ${ }^{17}$

${ }^{14}$ Assim como na arbitragem, na mediação se permite a condução do processo por vários co-mediadores.

${ }^{15}$ A legitimidade do resultado, em consequência, também é maior do que na arbitragem.

${ }^{16}$ Essa base mínima é maior ou menor conforme o tipo de técnica de mediação mais enfatizada pelo mediador.

17“"Em teoria, pelo fato de ser a opinião de um terceiro desinteressado, a parte em disputa geralmente tende a aceitá-la com mais facilidade do que se fosse dada pelo adversário. O mediador avaliador informa sobre os possíveis resultados da disputa, se levada ao Judiciário". [GT ARBITRAGEM. Glossário: métodos de resolução de disputas - RDs. In: AZEVEDO, André Gomma de (org.). Estudos em Arbitragem, Mediação e Negociação. Vol. 3. Brasília: Grupos de Pesquisa, 2004, p. 314]. Para um estudo mais completo sobre a distinção entre as práticas avaliadora e facilitadora, cf. RISKIN, Leonard L. Compreendendo as orientações, estratégias e técnicas do mediador: um padrão para iniciantes. Tradução de Henrique Araújo Costa. In: AZEVEDO, André Gomma (Org.). Estudos em Arbitragem, Mediação e Negociação. Brasília: Brasília Jurídica, 2002, p. 63-111.

Revista de Direito, Estado e Telecomunicações, v. 1, n. 1, p. 111-159 (2009)

DOI: https://doi.org/10.26512/lstr.vli1.21740 
O procedimento da mediação também pode fundamentar-se em uma técnica transformadora. Essa técnica busca utilizar como propulsores da resolução do conflito o 'empoderamento', que é um ganho de clareza sobre a visão do problema e uma maior capacidade de decidir autonomamente, e o reconhecimento mútuo, que se refere ao fato de uma parte também reconhecer como legítima a visão da outra sobre o conflito. ${ }^{18}$ Esse tipo de técnica é bastante eficaz em mediações interpessoais, não sendo aplicada intensamente a mediações comerciais ou empresariais, como as que são mais comuns no setor de regulação em telecomunicações.

O início da sessão de mediação dá-se com uma fala do mediador, que se apresenta e explica como o procedimento é realizado, buscando defini-lo junto com as partes. A mediação ocorre, em sua maior parte, em sessões conjuntas das partes com o mediador. Apesar da informalidade característica dessa forma de RD, recomenda-se que uma parte não interrompa a outra enquanto esta estiver expondo seus pontos. A confidencialidade do processo é uma característica fundamental da mediação, podendo haver sessões privadas entre uma parte e o mediador, para garantir um maior conforto na discussão de determinadas questões e na exposição de certos fatos e pontos de vista.

Como se percebe, além do preparo técnico para lidar com as questões específicas envolvidas ${ }^{19}$, o mediador precisa ter uma boa formação em teoria da negociação, que lhe permitirá identificar os interesses de cada parte e, com base nisso e na utilização de uma linguagem neutra, aproximá-las uma da outra.

\section{Experiências estrangeiras de métodos de resolução de disputas conduzidos pelo órgão regulador}

\section{Japão}

O Japão tem como marco regulatório do setor de telecomunicações a Lei Comercial de Telecomunicações (Telecommunications Business Law), que

${ }^{18}$ Sobre a mediação transformadora, cf. OLIVEIRA, Artur Coimbra de. Para a verificação da eficácia de uma mediação transformadora. In: AZEVEDO, André Gomma (Org.). Estudos em Arbitragem, Mediação e Negociação. Vol. 4. Brasília: Grupos de Pesquisa, 2006. No prelo.

${ }^{19}$ Isso é ainda mais saliente no setor de telecomunicações. 
foi promulgada em 25 de dezembro de 1984, mas já foi emendada várias vezes desde então. Em 2001, recebeu uma emenda responsável pela criação da Comissão de Resolução de Disputas Comerciais em Telecomunicações (Telecommunications Business Dispute Settlement Commission ou denkitsûshin jigyô funsô shori iinkai), entidade que integra o Ministério das Comunicações do país. ${ }^{20}$

Tal Comissão é composta por cinco membros, indicados pelo Ministro das Comunicações e aprovados pelo Parlamento. Os próprios membros da Comissão são responsáveis pela eleição de seu presidente. O mandato é de três anos, sendo possível a recondução. ${ }^{21}$ A Comissão tem sob sua competência a mediação (assen) e a arbitragem (chüsai) de disputas concernentes à interconexão em telecomunicações. ${ }^{22}$ Ela não é um órgão independente, na medida em que se situa no âmbito do Ministério, e todas as petições solicitando a atuação da Comissão como mediadora ou árbitra devem ser dirigidas ao Ministro. ${ }^{23}$

No caso em que uma prestadora solicita um acordo de interconexão para outra prestadora e esta nega, ou quando a negociação entre as prestadoras falha, ou, ainda, quando as partes não conseguem chegar a um acordo sobre os termos do contrato, uma das partes em disputa pode recorrer à Comissão para mediar a disputa. ${ }^{24}$

${ }^{20}$ Cumpre observar que a regulação do setor de telecomunicações no Japão é titularidade do Ministério das Comunicações.

${ }^{21} \mathrm{O}$ Ministro tem autonomia para, justificadamente, exonerar membros da Comis são. No entanto, o ato, para ser válido, precisa da aprovação do Parlamento.

${ }^{22}$ Como se verá mais à frente, há outros casos além da interconexão que também são resolvidos pela arbitragem ou pela mediação da Comissão.

${ }^{23}$ Não necessariamente as petições devem ser entregues no órgão regulador central, mas admite-se a entrega a agências de competência local - equivalentes aos postos avançados que a ANATEL possui nos estados brasileiros.

${ }^{24}$ De acordo com o artigo 35 da Telecommunications Business Law, é possível também que a parte cujo pedido de interconexão foi negado ou que não conseguiu chegar a um acordo de interconexão com a outra solicite ao Ministro para que interceda e decida sobre a obrigatoriedade de interconexão bem como o estabelecimento das respectivas tarifas. Essas disposições são as vias originais de resolução de disputas, presentes na Telecommunications Business Law antes da criação da Comissão em comento. Se alguma das partes já iniciou o procedimento por essa via ou por meio da arbitragem, ela não tem capacidade para solicitar a mediação pela Comissão. Esta, por outro lado, também pode vir a ter uma atuação Revista de Direito, Estado e Telecomunicações, v. 1, n. 1, p. 111-159 (2009)

DOI: https://doi.org/10.26512/lstr.vli1.21740 
Conduzir a mediação é competência privativa da Comissão (seus membros ou outros funcionários listados previamente), não se abrindo a possibilidade para as partes indicarem um mediador privado. A mediação pode ser conduzida por mais de um mediador. Permite-se à Comissão declinar de mediar a disputa se ela não considerar a mediação como um meio adequado de resolução ao caso específico, se o confronto entre as partes é grande a ponto de impedir a formação de um compromisso entre elas ou se ela verificar que a mediação é procurada por motivos escusos. Nesse caso, serão informadas ao solicitante as razões da negativa.

Os procedimentos aplicáveis à mediação são detalhados por normas editadas pela própria Comissão. O pedido de mediação deve ser feito por escrito, em que a parte solicitante indica as questões a serem mediadas pela Comissão. Em seguida, notifica-se a parte requerida para responder as questões trazidas pela requerente.

A mediação é conduzida a portas fechadas, podendo o mediador admitir a presença de outros no processo se for estritamente necessário ou apropriado. Todo material produzido no curso da mediação não fica à disposição do público. Isto só ocorrerá se as partes concordarem ou se a Comissão julgar apropriado divulgar determinado material, na medida em que isso não interfira negativamente no controle da Comissão sobre o processo, na resolução da disputa nem no funcionamento empresarial das partes.

A arbitragem pode ser requisitada à Comissão pelos mesmos motivos que se aplicam à mediação. No entanto, para que se proceda à arbitragem, é necessário que ambas as partes concordem e formalmente a requeiram. ${ }^{25} \mathrm{~A}$ arbitragem é conduzida por três funcionários da Comissão, nomeados por ela própria após serem indicados pelas partes de comum acordo.

Assim como ocorre na mediação, a arbitragem tem seus procedimentos detalhados pela Comissão. O padrão de pedido de arbitragem deve ser o mesmo para a mediação, indicando-se as questões que não foram objeto de acordo entre as partes e que, assim, devem ser julgadas pelos árbitros. Feito

nos procedimentos iniciados sob o art. 35. No entanto, essa atuação limitar-se-á a uma consulta, solicitada pelo Ministro, sobre a disputa.

${ }^{25}$ Assim como na mediação, se já está pendente o conflito pelo procedimento do art. 35, não poderá haver arbitragem. 
o pedido por uma das partes, a parte solicitada tem prazo para responder as questões levantadas pela requerente. ${ }^{26}$

$\mathrm{O}$ procedimento de nomeação dos árbitros inicia-se com o envio pela Comissão de uma lista de funcionários pré-determinada. A partir do requerimento de arbitragem feito pelas partes, se a Comissão inferir de algum fato envolvido na disputa que há dúvida quanto à honestidade ou à imparcialidade de algum dos funcionários listados, retirá-lo-á da lista antes de enviá-la às partes. Recebida a lista, cada parte terá duas semanas para indicar os nomes das pessoas que aceita como árbitras. Deve haver um consenso entre elas na escolha desses nomes; se houver consenso entre mais de três nomes, toda a indicação será considerada inválida. Se as partes não procederem a essa escolha (ou fizerem-na fora do prazo), a própria Comissão apontará os três árbitros. ${ }^{27} \mathrm{O}$ árbitro-presidente é escolhido pela Comissão e é responsável por determinar questões procedimentais e por conduzir o exame das questões arbitradas.

Se uma das partes considerar que a turma de árbitros não possui competência para julgamento de uma questão específica, deve mencioná-lo imediatamente após o surgimento da questão. Admite-se à turma de arbitragem determinar que uma das partes adote medida cautelar ou provisória se a questão em disputa merecer uma medida nesse sentido.

Haverá audiências no processo de arbitragem, de ofício ou a requerimento das partes, em que estas terão oportunidade de expor plenamente seus argumentos, além de entregá-los por escrito. Se alguma das partes ausentar-se a uma audiência, esta não será invalidada. É permitido às partes complementar suas declarações ao longo da arbitragem. ${ }^{28}$

O painel de árbitros deve expor as provas e as evidências que sustentam sua decisão, sendo defeso a qualquer das partes divulgar conhecimentos obtidos da outra parte por meio dessa exposição. Se uma das partes recusa-

${ }^{26} \mathrm{Se}$ a parte requerida não concordar com a arbitragem, deve informar isso em sua resposta.

${ }^{27}$ Permite-se à(s) parte(s) recorrer à Comissão se considerar(em) a escolha de um dos nomes inapropriada, solicitando o afastamento do árbitro e dando razões para isso.

${ }^{28}$ Assim como ocorre na mediação, o processo de arbitragem é confidencial, não ficando exposto à consulta pública. Só se a admite nas mesmas hipóteses em que se promove a publicidade das informações na mediação. A Comissão só publica, a princípio, a data do pedido de arbitragem e a data do término do processo.

Revista de Direito, Estado e Telecomunicações, v. 1, n. 1, p. 111-159 (2009)

DOI: https://doi.org/10.26512/lstr.vli1.21740 
se a entregar ou não providencia injustificadamente os documentos ou os objetos requisitados pelos árbitros, a alegação da outra parte sobre eles é considerada verdadeira.

O tribunal arbitral pode ainda solicitar o parecer de um especialista sobre determinada questão. Nesse caso, as partes poderão enviar documentos, informações ou outras questões para buscarem a análise do especialista. Feita a análise por escrito, poder-se-á tê-lo - o especialista - em audiência para responder a perguntas das partes ou para que cada uma conduza um especialista próprio para exposição de sua análise individual.

Antes de proferir a sentença arbitral, o painel de árbitros pode tentar alcançar, entre as partes, uma solução amigável. Caso se a alcance em parte das questões discutidas ou em sua totalidade, os árbitros podem, a requerimento das partes, considerar esse consenso como trecho integrante da decisão, dando-lhe os respectivos efeitos.

A turma de árbitros termina o processo sem emitir julgamento quando não tiver competência para decidir as questões envolvidas, quando a parte requerente não prossegue participando dos procedimentos ou desiste de continuar, quando ambas as partes concordarem em cancelar o procedimento, quando se obtém uma conciliação entre elas ou quando, a juízo do próprio painel arbitral, a continuação dos procedimentos tornar-se desnecessária ou impossível.

Concluídos todos os procedimentos de exposição pelas partes e de recolhimento de informações necessárias para a decisão, a turma arbitral deve proferir o laudo. Além da qualificação das partes, a sentença arbitral deve conter a decisão propriamente dita, incluindo os fatos considerados e os fundamentos, além da data e do local de decisão. Não há qualquer procedimento recursal em relação à decisão arbitral.

Depois de proferido o laudo arbitral, em um prazo de trinta dias, o painel de árbitros pode proferir correção, interpretação ou decisão adicional a requerimento de uma das partes. A decisão adicional deve ser sobre matéria já discutida ao longo dos procedimentos, porém omitida no laudo.

Esses procedimentos de arbitragem e de mediação também se aplicam, por disposição expressa da Telecommunications Business Law e de normas da Comissão, a disputas referentes a compartilhamento de infraestrutura (desde elementos de rede até utilização de terrenos e edifícios), a venda de serviços entre prestadoras a preço de atacado, bem como a quaisquer 
disputas concernentes à formação de acordos necessários para a boa prestação de serviços entre operadoras.

\section{Inglaterra}

Quando se analisam as formas de resolução de disputas na Comunidade Europeia, observa-se uma realidade peculiar. Em grandes disputas que ocorrem no continente, é mais comum utilizar-se a arbitragem do que o próprio Poder Judiciário. Isso ocorre porque as grandes disputas europeias não só no setor de telecomunicações, mas no de energia elétrica, de transportes e nos setores comerciais em geral - frequentemente envolvem mais de um país, visto que a maioria das grandes empresas é transnacional.

Confere-se, assim, um grande prestígio a esses métodos de resolução de disputas, na medida em que eles propiciam uma neutralidade de foro. Não se confere a decisão ao Poder Judiciário ou ao órgão regulador de um país específico, mas escolhem-se árbitros a partir do comum acordo das partes ou, ainda, apontam-se instituições de âmbito internacional que prestam o serviço de arbitragem em disputas comerciais. ${ }^{29}$ Isso é importante principalmente quando a disputa concerne a duas ou mais empresas com sede em diferentes países. ${ }^{30} \mathrm{Na}$ resolução de disputas em telecomunicações pelas autoridades reguladoras, essa tradição não é desprezada, como se verá.

$\mathrm{Na}$ Europa, há normas de âmbito continental promulgadas pelos respectivos DGs da União Europeia (Europe Union Framework Directives). O setor de redes e serviços de comunicação eletrônica é regido pela Diretiva 2002/21/EC, de 7 de março de 2002. Essa norma aborda, em seus artigos 20 e 21, a posição dos órgãos reguladores na resolução de disputas entre operadoras de telecomunicações em países regidos pela Diretiva.

${ }^{29}$ Têm-se, como exemplos dessas instituições, a Organização Mundial do Comércio, o Centro Internacional para Resolução de Disputas em Investimento (International Centre for Settlement of Investment Disputes - ICSID), que é parte do Banco Mundial, a World Intellectual Property Organization (WIPO) Arbitration and Mediation Center, e outras instituições privadas como a American Arbitration Association (AAA), a London Court of International Arbitration, a International Chamber of Commerce (ICC), entre outras.

${ }^{30}$ Pelas Convenções de Bruxelas e de Lugano sobre a Competência e o Julgamento de Questões Cíveis e Comerciais, uma parte pode ser processada apenas no EstadoMembro em que é domiciliada.

Revista de Direito, Estado e Telecomunicações, v. 1, n. 1, p. 111-159 (2009)

DOI: https://doi.org/10.26512/lstr.v1i1.21740 
Segundo esse instrumento normativo, a autoridade regulatória nacional deve decidir de forma vinculativa para as partes, no prazo máximo de quatro meses, quando uma delas requer solução a uma disputa referente a qualquer norma ou diretiva do setor - inclusive a própria Diretiva 2002/21/EC. No entanto, é dever dos Estados-Membros garantirem a capacidade de as autoridades regulatórias declinarem de resolver a disputa quando outros mecanismos - inclusive a mediação - existirem e contribuírem de maneira mais efetiva para a resolução da disputa em um prazo aceitável. Assim, sendo cabíveis a arbitragem ou a mediação no caso, a autoridade regulatória informa às partes que não solucionará a disputa. Se esses mecanismos de resolução de disputa não trouxerem resultado em quatro meses, a autoridade regulatória deve se comprometer a decidir a questão.

Na possibilidade de uma disputa surgir entre duas empresas domiciliadas em países distintos, pode-se requerer a decisão a qualquer das autoridades regulatórias nacionais envolvidas. Elas, entretanto, trabalharão em conjunto para se alcançar uma decisão ao caso. Nesse tipo de conflito, também se aplica a possibilidade de as autoridades regulatórias declinarem, se existirem outros métodos de resolução de disputa. Sendo este o caso, só decidirão depois de não se ter alcançado resultado com esses métodos após quatro meses.

A decisão do(s) órgão(s) regulador(es) é pública, respeitando-se, todavia, o requerimento da(s) parte(s) pela confidencialidade de aspectos negociais da(s) empresa(s). Essa decisão não faz o acesso das partes ao Poder Judiciário precluir, podendo elas ir à busca de uma revisão judicial do mérito analisado. ${ }^{31}$

Nas suas decisões, as autoridades regulatórias nacionais devem observar alguns princípios. São esses: garantir que os usuários beneficiem-se ao máximo em relação ao poder de escolha, ao preço e à qualidade, garantir que não haja distorções ou restrições no mercado, encorajar investimentos em infraestrutura e promover inovações, ensejar o uso eficiente de radiofrequências e de recursos de numeração, remover barreiras ao

${ }^{31}$ Para uma discussão mais aprofundada dessa questão, cf. artigo do Prof. Fábio Bassan intitulado "Dispute resolution in telecommuncations: fast track or double track", in: Anais do I Seminário Internacional de Regulação de Serviços Públicos: Direito Comparado da Energia Elétrica e das Telecomunicações. Brasília: Universidade de Brasília; Santa Cruz do Sul: EDUNISC, 2007. 
compartilhamento de infraestrutura e à prestação de serviços, encorajar a existência de redes, serviços e conectividade transnacionais, garantir que todos os usuários tenham acesso a um serviço universal, proteger os consumidores nas negociações com as operadoras, criando inclusive mecanismos próprios de resolução de disputas consumidor-operadora, ensejar a proteção de dados pessoais e da privacidade, promover a transparência das tarifas e das condições de uso de serviços de telecomunicações de interesse coletivo, suprir as demandas das minorias por acessibilidade e garantir a integridade e a segurança das redes públicas de telecomunicação.

Diante dessa diretiva europeia, o Reino Unido promulgou o Communications Act de 2003, criando o Office of Communications $(\text { Ofcom })^{32}$, órgão regulador do setor de telecomunicações, que trouxe novas atribuições à atividade regulatória. Entre tais atribuições, está a competência de resolver disputas entre operadoras de telecomunicações. O Communications Act é um documento extenso e trata pormenorizadamente desse papel do Ofcom.

Primeiramente, para que se tenha a resolução de uma disputa pelo Ofcom, basta que uma das partes a solicite. Na linha da diretiva da União Europeia, a disputa só será resolvida pelo órgão regulador se não houver meios alternativos para resolver a disputa, caso esses meios alternativos sejam cabíveis ao tipo de disputa. Seja qual for o posicionamento do órgão, as partes são notificadas. No caso de o Ofcom declinar e, depois de iniciado o procedimento alternativo de resolução de disputa, não se alcançar uma conclusão em quatro meses, uma das partes tem o direito de solicitar que o órgão resolva a disputa e este é obrigado a fazê-lo. Neste caso, o processo anterior será continuado. ${ }^{33}$

No procedimento de resolução de disputa, o Ofcom tem o poder de: declarar os direitos e as obrigações das partes em disputa; firmar uma direção para as partes, fixando os termos e as condições das transações entre elas e obrigando-as a entrar em processo de negociação com base nessas

${ }^{32} \mathrm{O}$ Office of Communications (Ofcom) herdou as competências do antigo Office of Telecommunications (Oftel) e da extinta Radiocommunications Agency.

${ }^{33}$ Também serão consideradas as decisões já tomadas no procedimento alternativo iniciado e não terminado, devendo elas ser ratificadas. 
condições; determinar que uma das partes cumpra o pagamento para com a outra; e/ou modificar ou revogar condições gerais, de universalização, condições de acessibilidade etc.

O órgão regulador tem o poder de requerer das partes todas as informações necessárias e resolver se é apropriado que o Ofcom decida no caso ou se deve consultar outros estados-membros, e ainda pode exigir todas as informações que sejam importantes para a análise da disputa e para a decisão. O órgão tem o poder de realizar essas solicitações não só às partes, mas a terceiros que possuam informações relevantes nesse sentido.

Não há cobrança de pagamento por essa prestação de serviço do Ofcom, a não ser que a parte que solicitou a decisão do órgão o tenha feito em condições abusivas, vexatórias ou frívolas. A decisão deve ser entregue pelo órgão em até quatro meses. Uma cópia da decisão, com seus fundamentos, é enviada para cada uma das partes. Os trechos da decisão que o órgão considerar apropriados para ir a público serão publicados.

Da decisão do Ofcom cabe apelação apenas para o Tribunal, em procedimento judicial próprio. Deve-se notificar o órgão regulador da apelação citando a decisão apelada e os fundamentos da apelação. Tais fundamentos devem permitir identificar se o que levou a parte a apelar foi um erro de fato ou de direito - ou ambos - e se a parte apela do exercício da discricionariedade pelo Ofcom.

Ao lidar com a apelação, o Tribunal deve, de acordo com normas editadas por ele próprio, remeter as questões que envolvem controle de preço à entidade reguladora da concorrência. A decisão do Tribunal também pode, por sua vez, ser recorrida, mas tal recurso passa por um juízo de admissibilidade e deve se restringir a questões de legalidade e não de fatos. Portanto, como se vê, o Ofcom, nos procedimentos de resolução de disputas, atua, de uma forma bastante singular, no papel análogo ao de uma primeira instância judiciária.

\section{Estados Unidos}

Nos Estados Unidos, o Telecommunications Act, após a reforma de 1996, trata, em sua Seção 252, da resolução de disputas entre empresas prestadoras de serviços de telecomunicações que tanjam a Seção 251. A Seção 251, por sua vez, trata da interconexão de redes. No entanto, o legislador deixa claro que as disputas não necessariamente versarão 
restritivamente sobre a interconexão em si, podendo abarcar, além das obrigações padrões previstas nas subseções (b) e (c) da Seção $251^{34}$, serviços e elementos de rede negociados entre as empresas.

Ao receber o pedido de interconexão, de prestação de serviço ou de elementos de rede por outra empresa, é dever da incumbent abrir-se às negociações. No curso dessa negociação, qualquer das partes tem direito a solicitar o ingresso da Agência estadual como mediadora de conflitos que surjam. ${ }^{35}$

No entanto, se nem a negociação, nem a mediação produzirem resultados, qualquer das partes em negociação pode solicitar à Agência estadual, entre o $135^{\circ}$ e o $160^{\circ}$ dia após o pedido de negociação inicial, que atue como árbitra de questões irresolvidas. Assim, a parte que solicitar a arbitragem pela Agência tem o dever de, na petição, indicar as questões não resolvidas, a posição de cada uma das partes em relação a essas questões e os pontos já acordados, se houver. ${ }^{36} \mathrm{~A}$ outra parte - a que não peticionou tem o direito de responder as informações entregues pela requerente até vinte e cinco dias depois de a Agência receber o pedido inicial de arbitragem.

${ }^{34}$ Tais obrigações impostas às empresas são, em resumo, não impor limitações abusivas à revenda dos seus serviços, possibilitar portabilidade numérica nos termos exigidos pela Agência, garantir a paridade de discagem (ou seja, o acesso mútuo a números de telefone, serviços operacionais, catálogo de assinantes etc.), compartilhar a infraestrutura física de telecomunicações (postes, dutos etc.), firmar acordos de compensação mútua entre os usos recíprocos de rede, possuir boa-fé nas negociações, prover o unbundling, publicar informações sobre eventuais mudanças nos acessos à rede e providenciar as instalações que se fizerem necessárias para a interconexão ou para o acesso a elementos de rede.

${ }^{35}$ Eventualmente, a Federal Communications Commission (FCC), órgão responsável pela regulação do setor de telecomunicações em âmbito federal, por meio da Market Disputes Resolution Division, também faz uso da mediação para evitar a propositura de uma reclamação formal (prevista na Seção 208 do Telecommunications Act) contra uma empresa operadora de telecomunicações. A Seção 208 trata da possibilidade de se propor reclamação contra ação ou omissão de empresa de telecomunicações que se tenha feito contrária ao disposto no Telecommunications Act.

${ }^{36} \mathrm{~A}$ parte que solicitar a arbitragem também tem o dever de enviar cópias dos documentos entregues à Agência à outra parte até o dia dessa entrega.

Revista de Direito, Estado e Telecomunicações, v. 1, n. 1, p. 111-159 (2009)

DOI: https://doi.org/10.26512/lstr.vli1.21740 
Recebida a petição e a resposta pela Agência, ela tem o dever de, ao tratar as questões, ater-se ao que foi apontado nesses documentos. ${ }^{37}$ As partes têm o dever de atender os eventuais pedidos de esclarecimento que a Agência julgar necessários para a melhor compreensão da questão. ${ }^{38} \mathrm{~A}$ Agência, por sua vez, tem o dever de concluir a resolução das questões em até nove meses contados a partir da data do pedido de negociação feito pela empresa solicitante à incumbent. ${ }^{39}$

Ao resolver as questões, a Agência deve, além de estabelecer o valor das tarifas de interconexão, de serviços ou de elementos de rede, determinar o prazo para o cumprimento dessa decisão. O estabelecimento dessas tarifas é feito com base nos custos, no princípio da não discriminação do acesso às redes e em um lucro razoável para a empresa proprietária da rede.

Para cumprir a determinação legal de que haja compensação financeira mútua entre o tráfego das duas redes ao utilizarem-se uma da outra, a Agência deve observar se as condições contratuais tratam desse acesso recíproco de redes e se os valores decorrentes desse acesso aproximam-se dos custos adicionais necessários para que se termine a chamada na outra rede. A Agência, por outro lado, tem o impedimento de determinar privativamente o valor desses custos adicionais e de desconsiderar acordos que já existam e tenham como base obrigações recíprocas - e não necessariamente valores financeiros.

É importante ressaltar que a Agência terá controle sobre qualquer contrato de interconexão mesmo quando as partes cheguem a todos os seus termos por meio de negociação, mediação ou de arbitragem, seja privada, seja feita pela própria Agência. Para serem válidos, os contratos de interconexão precisam ser homologados. ${ }^{40}$ Serão rejeitados os termos ou os

${ }^{37}$ Isso nada mais é que a aplicação do princípio dispositivo.

${ }^{38}$ Presume-se a má-fé de qualquer empresa que não colabore com a atuação da Agência como árbitra ou mediadora.

${ }^{39}$ E também dever da Agência, ao resolver qualquer disputa, garantir de ofício o cumprimento dos deveres expostos na nota 34 supra. Se ficar provado que a Agência estadual falhou ao arbitrar uma disputa (Seção 252, (e), (5) - "fails to act to carry out its responsibility"), pode-se requerer à $F C C$ que avoque suas competências para resolução daquela disputa específica.

${ }^{40}$ As companhias operadoras do antigo sistema Bell têm um regime específico: devem apresentar à Agência estadual uma declaração contendo os valores normalmente cobrados das operadoras locais (dentro do estado) e os termos que 
contratos que discriminem uma operadora de telecomunicações que não é parte do acordo, que não sejam coerentes com a conveniência, a necessidade ou o interesse públicos ou que não cumpram o determinado na Seção 251 e em sua regulamentação. ${ }^{41}$ É permitido às Agências estaduais criar outros requisitos para a homologação dos contratos de interconexão. ${ }^{42}$

Um ponto interessante e que merece destaque é o limite imposto ao Poder Judiciário no que tange a esses contratos: "Nenhum tribunal do estado terá competência para rever a ação da Agência estadual em aprovar ou rejeitar um acordo sob esta Seção". ${ }^{43}$ Permite-se a revisão judicial por tribunais federais apenas em caso de descumprimento do disposto nas seções 251 e 252 do Telecommunications Act.

Todos os acordos homologados devem ser postos à livre consulta do público para serem vistos e copiados em até dez dias. Exige-se da empresa que teve seu contrato homologado a disponibilidade da interconexão, do serviço ou do elemento de rede a outras empresas nos mesmos termos e condições.

Assim, concluídas as disposições pelo Telecommunications Act, abre-se às Agências estaduais a competência para uma regulamentação minudenciada. A partir daí, há muitas variações nas questões que são escolhidas para serem regulamentadas com maior profundidade. Devido à impossibilidade prática de se dar um panorama de todos os 51 estados americanos, foi escolhida a regulamentação de arbitragem e de mediação do estado da Dakota do Norte, que parece ter feito um trabalho mais detalhado sobre o tema.

$\mathrm{Na}$ Dakota do Norte, no regulamento de práticas e procedimentos do âmbito da Agência estadual (public service commission), há um capítulo

garantem o cumprimento do disposto na Seção 251 e na sua regulamentação. Isso não lhes exime de se abrir à negociação quando uma outra empresa lhes solicitar interconexão, venda de serviços ou compartilhamento de elementos de rede.

${ }^{41} \mathrm{~A}$ urgência e a importância da aprovação desses contratos para as empresas ensejou a criação da figura da homologação por omissão: se a Agência não se pronunciar em até 90 dias nos acordos negociados ou em até 30 dias nos acordos arbitrados, considera-se o contrato aprovado.

${ }^{42}$ Também é permitido às Agências cobrar custas de valor moderado pelo procedimento de homologação.

${ }^{43}$ ESTADOS UNIDOS DA AMÉRICA. Federal Telecommunications Act, Seção 252, (e), (4). Tradução livre do original.

Revista de Direito, Estado e Telecomunicações, v. 1, n. 1, p. 111-159 (2009)

DOI: https://doi.org/10.26512/lstr.vli1.21740 
dedicado à arbitragem (69-02-10) e outro à mediação (69-02-11). Ambos os procedimentos - a mediação e a arbitragem - referem-se às disposições já tratadas do Telecommunications Act (Seções 251 e 252).

$\mathrm{O}$ procedimento de mediação utilizado para a busca de um acordo em venda de serviços, interconexão ou elementos de rede não é competência privativa da Agência estadual e as partes podem, a seu próprio custo, buscar um mediador privado. Todavia, muitas vezes elas não chegam a um acordo sobre ir ou não a um mediador. Assim, permite-se que uma das partes solicite à Agência que atue como mediadora na negociação. A Agência, ao receber o requerimento, apontará um mediador em dez dias.

Em princípio, são as partes que escolhem, de comum acordo, quem será o mediador. ${ }^{44}$ Isso é importante para a legitimidade da mediação e para a confiança que as partes depositarão nele. A Agência, então, aprová-lo-á ou não. Se o mediador for desqualificado pela Agência ou as partes não conseguirem chegar a um acordo sobre quem será o mediador, ela escolherá algum dos seus funcionários para atuar como mediador. Um fator a ser destacado é a previsão regulamentar do impedimento a que fica sujeito o funcionário que atuar como mediador: "O funcionário da Agência que serve de mediador não terá permissão de participar no procedimento de arbitragem ou de aprovação para o mesmo acordo, a menos que as partes consintam". ${ }^{45}$ Outro ponto importante é que o regulamento diz taxativamente que o mediador não possui autoridade para compelir uma decisão. Isso deve ser interpretado tanto no sentido de proferir a decisão, quanto no sentido de forçar um ponto de vista próprio. ${ }^{46}$

O princípio da boa-fé nas negociações é concretizado pelo regulamento de mediação como “(...) disposição em encontrar-se em horários e lugares

${ }^{44}$ São as próprias partes que contratam diretamente os serviços do mediador privado. A Agência, no entanto, determina um ou mais funcionários para assessorar tecnicamente o mediador.

${ }^{45}$ DAKOTA DO NORTE. Article 69-02: Practice and Procedure. Chapter 69-02-11: Mediation. [on line] Disponível na Internet via WWW. URL: http://www.legis.nd.gov/information/acdata/html/69-02.html (Consultado em 18.04.2006). Tradução livre do original.

${ }^{46}$ Não se pretende, ao fazer essa proibição, o impedimento do uso da mediação avaliadora. Neste tipo de mediação, o mediador não força um resultado a ser aceito pelas partes, mas apenas opina quanto às questões de fato e de direito quando solicitado para fazê-lo. O regulamento deixa isso claro posteriormente.

Revista de Direito, Estado e Telecomunicações, v. 1, n. 1, p. 111-159 (2009) 
razoáveis com o objetivo e o propósito de fornecer e trocar informações necessárias para se obter uma negociação efetiva, cooperando com o processo de mediação, e negociar com uma atitude de abertura e visando ao estabelecimento de um acordo". ${ }^{47}$

Feito o requerimento de mediação à Agência, as partes têm quinze dias para entregar um documento contendo uma lista das questões em disputa e sua visão em cada uma dessas questões. O primeiro encontro da mediação ocorre em dez dias após o recebimento desses documentos e tem o objetivo de estabelecer um cronograma para o processo e de identificar, limitar e simplificar as questões em disputa. A partir daí, o mediador conduzirá todas as sessões e terá controle sobre os procedimentos, que são todos privativos, isto é, fechados ao público, em decorrência do princípio da confidencialidade. É permitido ao mediador conversar individualmente com cada parte (ou seu advogado) se considerar conveniente para possibilitar que os participantes fiquem mais próximos de um acordo. Não é permitida qualquer comunicação entre as partes sem a presença do mediador.

O mediador não tem competência para aconselhar jurídica ou legalmente as partes e as suas eventuais declarações a respeito de normas ou políticas não têm efeito vinculativo sobre a Agência. Ainda assim, permite-se ao mediador, além de facilitar a negociação entre as partes, propor alternativas para a resolução da disputa em qualquer momento do processo.

Há quatro fins possíveis para uma mediação feita sob o regulamento da Dakota do Norte: a afirmação de um acordo pelas partes, a notificação feita por uma das partes à Agência de que a mediação foi cancelada, a interrupção do processo por falta de boa-fé na negociação pela(s) parte(s) ou a notificação feita pelo mediador à Agência de que a respectiva mediação é desnecessária.

Se alguma das partes deseja terminar o processo de mediação sem alcançar um acordo, deve explicar à Agência os seus motivos. Se o mediador terminar a mediação antes de se alcançar um acordo, também deve justificar seus atos à Agência. É possível que, tendo a(s) parte(s) ou o

${ }^{47}$ DAKOTA DO NORTE. Article 69-02: Practice and Procedure. Chapter 69-02-11: Mediation. [on line $]$ Disponível na Internet via WWW. URL: http://www.legis.nd.gov/information/acdata/html/69-02.html (Consultado em 18.04.2006). Tradução livre do original.

Revista de Direito, Estado e Telecomunicações, v. 1, n. 1, p. 111-159 (2009)

DOI: https://doi.org/10.26512/lstr.vli1.21740 
mediador terminado a mediação sem um acordo, concluam o procedimento tentando resolver suas diferenças. ${ }^{48}$

$\mathrm{Na}$ arbitragem, exige-se que a parte seja representada por seu advogado. O procedimento tem início formalmente com a entrega do pedido de arbitragem por uma das partes em disputa. Além de cumprir as exigências do Telecommunications Act na petição inicial, a parte requerente deve também expor uma narrativa de todo o processo de negociação e de mediação, em caso dele ter existido. Recomenda-se que as partes indiquem quais os fundamentos legais de sua posição e, em caso de disputas de preços, apresentem estudos de custos e propostas de tarifas.

Pelo fato de a arbitragem ser um procedimento com certo grau de flexibilidade, permite-se às partes requerer a imposição de determinadas condições - na medida em que forem justificadas -, fazer uma proposta de cronograma para implementação dos termos do acordo e remeter outras propostas de interconexão já feitas perante a Agência.

É responsabilidade das partes - e elas devem fazê-lo em até quinze dias após o requerimento de arbitragem estar completo - o fornecimento dos dados de pelo menos dois árbitros imparciais aceitos por todas as partes da negociação. Se as partes não conseguem concordar entre si, cada uma deve entregar separadamente os dados de pelo menos dois árbitros considerados aceitáveis. A partir dessa listagem, a Agência seleciona um árbitro considerado qualificado. Se as partes sequer indicarem árbitros, a própria Agência determinará a escolha de um árbitro qualificado, sendo este um membro do seu quadro administrativo. ${ }^{49}$

Um fator importante regulamentado é a proibição de as partes travarem qualquer comunicação extraprocessual sobre o procedimento arbitral com o árbitro ou com algum seu assessor técnico, exceto para fins de agendamento de encontros. $\mathrm{O}$ árbitro e seus eventuais assessores técnicos são contratados diretamente pelas partes, que se fazem responsáveis por quaisquer honorários ou tarifas. É responsabilidade do árbitro marcar um encontro preliminar para discutir com as partes questões sobre o processo de

\footnotetext{
${ }^{48}$ Se se precisar apontar um novo mediador para o caso, dever-se-á reiniciar o processo de mediação.

${ }^{49} \mathrm{O}$ prazo para a Âgência determinar ou selecionar um árbitro para o caso é de 20 dias após o requerimento ter sido protocolizado.
} 
arbitragem, tais como estabelecer cronograma, identificar as questões a serem arbitradas, dentre outras. ${ }^{50}$ A Agência publicará uma nota sobre o encontro preliminar, identificando as questões em disputa, e todos os procedimentos da arbitragem são abertos a público. ${ }^{51}$

Não se admite a intervenção de terceiros no procedimento de arbitragem e, quando a Agência envolver-se no procedimento tanto no papel de interessada quanto no de assessora - para ajudar o esclarecimento de questões -, ambos os papéis jamais poderão ser prestados pela mesma pessoa. É dever das partes colaborar uma com a outra de boa-fé na troca de documentos e de informações relevantes para a resolução da disputa. ${ }^{52}$

Permite-se a audiência de testemunhas indicadas pelas partes. Para isso, estas devem trocar entre si em até vinte dias, contados a partir da resposta ao requerimento inicial, sua lista preliminar de testemunhas, identificando-as e indicando sobre qual tema cada uma delas vai se manifestar. ${ }^{53}$ A lista final de testemunhas deve ser entregue ao árbitro e à outra parte em até sete dias antes do encontro preliminar. No mesmo prazo, deve-se entregar ao árbitro um documento conciso a respeito de sua posição na disputa, das justificativas legais para isso e das provas que pretende apresentar. ${ }^{54}$

${ }^{50}$ Exige-se, na regulamentação de arbitragem em telecomunicações da Dakota do Norte, que esse encontro preliminar seja feito em até 200 dias contados a partir da data de solicitação de negociação.

${ }^{51}$ Isso não quer dizer que todas as informações das partes estarão disponíveis a público. É possível, a requerimento justificado feito por elas, que determinadas informações não sejam divulgadas.

${ }^{52} \mathrm{Se}$ alguma das partes não promove essa troca informal de informações e de documentos, a(s) outra(s) parte(s) pode (m), administrativamente ou perante o árbitro, apresentar um requerimento formal para a apresentação das informações ou dos documentos. A parte que receber a notificação desse requerimento deve cumprir os prazos impostos e apresentá-los.

${ }^{53} \mathrm{Em}$ geral, quando o procedimento de arbitragem da Dakota do Norte trata da antecipação do tema que a testemunha abordará, refere-se às chamadas testemunhas técnicas e não testemunhas de fato, isto é, pessoas que, preparadas tecnicamente, darão parecer sobre as questões discutidas.

${ }^{54}$ As partes podem, a qualquer momento, retornar ao procedimento de mediação se considerarem conveniente. Fazendo isso, pode-se envolver o árbitro na mediação sem torná-lo impedido de continuar atuando no processo de arbitragem.

Revista de Direito, Estado e Telecomunicações, v. 1, n. 1, p. 111-159 (2009)

DOI: https://doi.org/10.26512/lstr.vli1.21740 
Iniciados os encontros e as discussões, todas devem ser taquigrafadas e uma cópia das notas taquigráficas deve ser enviada à Agência. ${ }^{55}$

Em referência à decisão pelo árbitro, o regulamento dispõe que a técnica decisória a ser utilizada é a arbitragem de oferta final (final offer arbitration), que, segundo o regulamento, consiste em “(...) um procedimento sob o qual cada parte apresenta uma oferta final sobre as questões sujeitas à arbitragem e o árbitro seleciona, sem qualquer modificação, uma das ofertas finais entregues a ele ou porções de cada uma". ${ }^{56} \mathrm{O}$ árbitro tem discricionariedade para escolher entre a arbitragem de oferta final "empacotada" e a arbitragem de oferta final "questão-porquestão". A primeira refere-se à escolha pelo árbitro de uma das ofertas finais completa, a segunda trata da possibilidade de escolha de partes de cada oferta. A Agência pode, eventualmente, determinar que o árbitro utilize uma outra variação da arbitragem de oferta final.

É possível que, mesmo depois de as partes entregarem as ofertas finais, elas prossigam em negociação e apresentem outras ofertas finais posteriormente. Para possibilitar isso, o árbitro deve aguardar até quinze dias contados a partir da entrega das primeiras ofertas finais antes de proferir o laudo. Se nenhuma das ofertas finais possibilitar o cumprimento das condições do acordo estabelecidas nas Seções 251 e 252 do Telecommunications Act, o árbitro deve tomar providências para proferir uma sentença que as contemple, seja pedindo que as partes apresentem

${ }^{55}$ É a Agência que indica o taquígrafo, mas as partes são responsáveis pelo pagamento por seus serviços diretamente a ele.

${ }^{56}$ DAKOTA DO NORTE. Article 69-02: Practice and Procedure. Chapter 69-02-10: Arbitration. [on line] Disponível na Internet via WWW. URL: http://www.legis.nd.gov/information/acdata/html/69-02.html (Consultado em 18.04.2006). Traduçã̃o livre do original.

Sobre isso, pode-se complementar: "Em virtude dessa modificação no processo arbitral, é comum as partes fazerem ofertas consideradas pelas mesmas como justas, pois pretendem persuadir o árbitro a escolhê-las. Assim, evita-se que as partes demandem, na arbitragem, valores acima do que realmente pensam ser corretos ou justos". [GT ARBITRAGEM. Glossário: métodos de resolução de disputas - RDs. In: AZEVEDO, André Gomma de (org.). Estudos em Arbitragem, Mediação e Negociação. Vol. 3. Brasília: Grupos de Pesquisa, 2004, p. 303-4]. 
novas ofertas finais, seja desprezando as ofertas finais e tomando uma decisão que procure estar de acordo com tais condições. ${ }^{57}$

\section{Brasil}

\section{Mapeamento das possibilidades de atuação da ANATEL para dirimir disputas entre operadoras de telecomunicações}

No Brasil, não há propriamente um procedimento único de resolução de disputas entre operadoras de telecomunicações que contemple todos os tipos de conflito. O marco regulatório do setor de telecomunicações - a Lei Geral de Telecomunicações (LGT) ${ }^{58}$ - finca os marcos de atuação da ANATEL nessas disputas:

Art. 19. À Agência compete adotar as medidas necessárias para 0 atendimento do interesse público e para o desenvolvimento das telecomunicações brasileiras, atuando com independência, imparcialidade, legalidade, impessoalidade e publicidade, e especialmente:

(..)

XVII - compor administrativamente conflitos de interesses entre prestadoras de serviço de telecomunicações.

A ANATEL, por sua vez, criou, a partir dessa determinação, basicamente três "portas" normativas diferentes que podem ser acessadas por operadoras de telecomunicações em caso de disputa: (1) o procedimento para resolução de disputas em interconexão, (2) o procedimento para resolução de conflitos em compartilhamento de infraestrutura envolvendo agentes dos setores de telecomunicações, elétrico e petrolífero e (3) a arbitragem e a mediação exercidas pela Agência, que se aplica aos casos de compartilhamento de infraestrutura entre prestadoras de serviços de telecomunicações, bem como a quaisquer outras disputas entre operadoras

${ }^{57} \mathrm{O}$ laudo arbitral deve conter uma lista das provas apresentadas, uma apresentação da discussão travada entre as partes, esclarecendo a posição de cada uma, um acordo proposto para as questões arbitradas e as recomendações finais do árbitro que se fizerem necessárias ou convenientes.

${ }^{58}$ BRASIL. Lei n. 9.472, de 16 de julho de 1997. Dispõe sobre a organização dos serviços de telecomunicações, a criação e funcionamento de um órgão regulador e outros aspectos institucionais, nos termos da Emenda Constitucional n. 8, de 1995.

Revista de Direito, Estado e Telecomunicações, v. 1, n. 1, p. 111-159 (2009)

DOI: https://doi.org/10.26512/lstr.vli1.21740 
que se subsumam às hipóteses previstas nos contratos de concessão ou diretamente no Regimento Interno da Agência.

No caso das disputas referentes à interconexão de redes entre operadoras, a LGT traz ainda outro dispositivo que merece destaque:

Art. 153. As condições para a interconexão de redes serão objeto de livre negociação entre os interessados, mediante acordo, observado o disposto nesta Lei e nos termos da regulamentação.

$\S 1^{\circ}$. 0 acordo será formalizado por contrato, cuja eficácia dependerá de homologação pela Agência, arquivando-se uma de suas vias na Biblioteca para consulta por qualquer interessado.

$\S 2^{\circ}$. Não havendo acordo entre os interessados, a Agência, por provocação de um deles, arbitrará as condições para a interconexão. [grifo ausente no original]

Quando a LGT confere à ANATEL a competência de arbitrar as condições de interconexão, cai-se no dilema do que isso significa. $\mathrm{O}$ procedimento a ser adotado nesse caso será a arbitragem ou ocorrerá simplesmente um arbitramento pela Agência das condições de interconexão?

$\mathrm{O}$ art. $3^{\circ}$ da lei de criação da Agência Nacional de Energia Elétrica (ANEEL) - Lei n. 9.427/1996 - faz referência a dispositivo semelhante. ${ }^{59}$ Na ANEEL, dá-se a essa competência o sentido de arbitramento ${ }^{60}$, isto é, não há preocupação primordial com o estabelecimento de um procedimento cunhado pela ampla participação das partes e pela maior autonomia sobre o procedimento, argumentando cada uma em prol de seu interesse, em busca de uma decisão final, legítima e conclusiva, mas, sim, com uma avaliação

59““Art. $3^{\circ}$ Além das incumbências prescritas nos arts. 29 e 30 da Lei n. 8.987, de 13 de fevereiro de 1995, aplicáveis aos serviços de energia elétrica, compete especialmente à ANEEL: (...)VI - fixar os critérios para cálculo do preço de transporte de que trata o $\S 6^{\circ}$ do art. 15 da Lei n. 9.074, de 7 de julho de 1995, e arbitrar seus valores nos casos de negociação frustrada entre os agentes envolvidos" (BRASIL. Lei n. 9.427, de 26 de dezembro de 1996. Institui a Agência Nacional de Energia Elétrica - ANEEL, disciplina o regime das concessões de serviços públicos de energia elétrica e dá outras providências. Grifo ausente no original).

${ }^{60} \mathrm{Cf}$. COSTA, Henrique Araújo. Resolução alternativa de conflitos no setor elétrico nacional. In: AZEVEDO, André Gomma de (org.). Estudos em Arbitragem, Mediação e Negociação. Vol. 2. Brasília: Grupos de Pesquisa, 2003, p. 201. 
baseada em estimativas do valor a ser pago por uma empresa à outra. ${ }^{61}$ Assim, a atuação da ANEEL nesse procedimento é apenas uma forma de decisão administrativa, na qual se determinam as condições, os termos e as tarifas de interconexão.

$\mathrm{Na}$ ANATEL, para regulamentar o procedimento decisório do $\S 2^{\circ}$ do art. 153 da LGT, foi publicada a Resolução n. 410, de 2005, que revoga a de número 40, de 1998, aprovando o Regulamento Geral de Interconexão. Anexa a esse regulamento, está a definição do processo de arbitragem em interconexão.

Para se buscar a arbitragem pela ANATEL em conflitos de interconexão, basta uma das partes requerê-la, não necessitando da aquiescência da outra. Os processos de arbitragem são de competência da Comissão de Arbitragem, composta por três árbitros fixos ${ }^{62}$, sendo esta também responsável pela homologação dos acordos de interconexão elaborados pelas próprias partes ou por meio de arbitragem ou mediação privadas. ${ }^{63}$

A regra desse processo de arbitragem da ANATEL é a publicidade, podendo, a pedido das partes, conter informações tratadas de modo confidencial se houver "(...) risco à segurança do país ou de prejuízo para qualquer das partes (...)" ${ }^{64}$ Podem participar do processo de arbitragem regulamentado, além das partes, quaisquer pessoas que tiverem direitos ou

${ }^{61}$ Nesse sentido, a função administrativa aproxima-se de disposição do Código Tributário Nacional: "Art. 148. Quando o cálculo do tributo tenha por base, ou tome em consideração, o valor ou o preço de bens, direitos, serviços ou atos jurídicos, a autoridade lançadora, mediante processo regular, arbitrará aquele valor ou preço, sempre que sejam omissos ou não mereçam fé as declarações ou os esclarecimentos prestados, ou os documentos expedidos pelo sujeito passivo ou pelo terceiro legalmente obrigado, ressalvada, em caso de contestação, avaliação contraditória, administrativa ou judicial" (BRASIL. Lei n. 5.172, de 25 de outubro de 1966. Dispõe sobre o Sistema Tributário Nacional e institui normas gerais de direito tributário aplicáveis à União, Estados e Municípios. Grifo ausente no original).

${ }^{62} \mathrm{Os}$ árbitros são funcionários da Agência e a eles se aplicam as hipóteses de suspeição e impedimento do $\mathrm{CPC}$, sendo, se for o caso, substituídos por outro funcionário selecionado pelo Conselho Diretor.

${ }^{63} \mathrm{~A}$ possibilidade de se usar a arbitragem privada em vez do procedimento da Agência é prevista no art. 26 do referido documento. No entanto, para isso, nos termos da Lei n. 9.307/1996, as partes devem entrar em acordo, não bastando a provocação de apenas uma delas.

${ }^{64}$ BRASIL. Agência Nacional de Telecomunicações. Aprova o Regulamento Geral de Interconexão. Resolução n. 410, de 11 de julho de 2005, Anexo III. Art. $5^{\circ}$, § $1^{\circ}$.

Revista de Direito, Estado e Telecomunicações, v. 1, n. 1, p. 111-159 (2009)

DOI: https://doi.org/10.26512/lstr.vli1.21740 
interesses que possam ser afetadas pela decisão, além de organizações e associações legalmente constituídas.

Após o requerimento da(s) parte(s) pela arbitragem, o árbitro relator dará uma decisão de admissibilidade. ${ }^{65}$ Admitido, a parte requerida tem dez dias para responder, apresentando documentos e informações referentes à questão a ser decidida. Em seguida, cada parte tem prazo de cinco dias para a entrega de suas razões finais, devendo a decisão da Comissão ser proferida em até trinta dias. Para contribuir no ato decisório, a ANATEL pode, a seu próprio juízo, contratar peritos, devendo estes ser custeados pelas partes. Admite-se também a intervenção da procuradoria no processo, para entrega de parecer. As partes podem entrar em consenso sobre a controvérsia, porém não é papel da Comissão atuar como conciliador ou mediador - papel esse que, por outro lado, é ressaltado pelo art. $21, \S 4^{\circ}$, da Lei da Arbitragem. Se as partes alcançarem esse consenso, a Comissão homologá-lo-á.

Da decisão final da Comissão de Arbitragem em Interconexão cabe recurso ao Conselho Diretor, e da decisão do Conselho que julga o recurso ainda cabe pedido de reconsideração para o próprio Conselho. O regulamento do processo de arbitragem em interconexão não expõe qualquer vedação a discussões judiciais a partir da decisão final do Conselho Diretor, donde se interpreta que são plenamente possíveis. Nesse ponto, há expresso confronto com a Lei da Arbitragem (Lei n. 9.307/1996), que não admite qualquer recurso revisional de mérito ao Poder Judiciário, mas apenas pedido judicial de decretação de nulidade do laudo arbitral, nas hipóteses previstas em lei.

Como se observa, o procedimento instituído pelo Regulamento Geral de Interconexão em muito carece de mecanismos-chave do procedimento de arbitragem, tal como construído tradicionalmente, bem como destoa das disposições da Lei n. 9.307/1996, que regula a arbitragem no Brasil. Nessa esteira, pode-se sustentar que, em verdade, esse procedimento não se trata de arbitragem, mas de um processo administrativo de resolução de disputas em interconexão.

Surgindo algum conflito que envolva operadoras de telecomunicações, concernente a compartilhamento de infraestrutura, o procedimento a ser seguido depende das partes que estiverem em conflito. Se uma delas for

${ }^{65}$ Desta, cabendo recurso ao Conselho Diretor. 
operadora de telecomunicações e a outra se submeter à disciplina regulatória da ANP ou da ANEEL, a competência passa, por força das resoluções conjuntas ANEEL-ANATEL-ANP n. 1/1999 e n. 2/2001, para a Comissão de Resolução de Conflitos das Agências Reguladoras dos Setores de Energia Elétrica, Telecomunicações e Petróleo. ${ }^{66}$

O Regulamento Conjunto para Compartilhamento de Infraestrutura entre os Setores de Energia Elétrica, Telecomunicações e Petróleo, aprovado pela Resolução Conjunta ANEEL-ANATEL-ANP n. 1/1999, dispunha originalmente:

Art. 23. Eventuais conflitos surgidos em matéria de interpretação e aplicação deste Regulamento, quando do desenvolvimento das negociações de contratos de compartilhamento, serão equacionados pelas Agências, no exercício da função de órgãos reguladores, através de processo de arbitragem a ser definido em regulamento conjunto que será expedido pelas Agências. (Grifo ausente no original).

Essa redação do art. 23 foi, todavia, modificada com a Resolução Conjunta ANEEL-ANATEL-ANP n. 2/2001, que aprovou o Regulamento Conjunto de Resolução de Conflitos das Agências Reguladoras dos Setores de Energia Elétrica, Telecomunicações e Petróleo, passando a ter a seguinte dicção:

Art. 23. Eventuais conflitos de interesse entre agentes serão dirimidos pelas Agências em Regulamento Conjunto de Resolução de Conflitos das Agências Reguladoras dos Setores de Energia Elétrica, Telecomunicações e Petróleo a ser por elas expedido.

A referência à arbitragem, como se nota, foi suprimida. De fato, a Resolução Conjunta n. 2/2001 não criou um procedimento tipicamente arbitral, mas, sim, um processo de resolução administrativa da disputa, isto é, uma forma de decisão administrativa como outra qualquer, que, enquanto tal, admite pedido de reconsideração e ação judicial que rediscuta as questões. ${ }^{67}$

${ }^{66}$ REZIO, Juliana Oliveira. Resolução de Conflitos em Compartilhamento de InfraEstrutura. In: Revista Teletime, Ano 5, n. 41, fevereiro de 2002.

${ }^{67}$ Lê-se na Consulta Pública Conjunta ANEEL-ANATEL-ANP n. 2/2000: “(...) o presente Regulamento não trata de arbitragem civil e sim dos procedimentos administrativos, previstos na legislação dos setores de Telecomunicações, Energia Elétrica e Petróleo, para resolução de conflitos entre agentes destes setores, sendo obrigatória a submissão das partes ao juízo das Agências". (BRASIL. ANEELRevista de Direito, Estado e Telecomunicações, v. 1, n. 1, p. 111-159 (2009)

DOI: https://doi.org/10.26512/lstr.vli1.21740 
Mais comuns do que as disputas entre empresas dos diferentes setores regulatórios mencionados são as disputas em compartilhamento de infraestrutura entre as próprias operadoras de telecomunicações. Essas disputas têm sua base no Regulamento de Compartilhamento de Infraestrutura entre Prestadoras de Serviço de Telecomunicações, aprovado pela Resolução da ANATEL n. 274/2001. Esse regulamento, em seu art. 32, dispõe:

Art. 32. No Compartilhamento da Capacidade Excedente, previsto no art. 12 do Regulamento Conjunto para Compartilhamento de Infraestrutura entre os Setores de Energia Elétrica, Telecomunicações e Petróleo, caso as Prestadoras envolvidas sejam ambas pessoas jurídicas detentoras de concessão, permissão ou autorização para exploração de serviço de telecomunicações de interesse coletivo, esse Compartilhamento dá-se exclusivamente nos termos deste Regulamento. (Grifo ausente no original).

Isso significa que as disputas surgidas entre operadoras de telecomunicações não se submetem ao Regulamento Conjunto anteriormente mencionado, mas às formas compositivas previstas no próprio regulamento de compartilhamento de infraestrutura, aprovado pela Resolução n. 274. Essas formas são a arbitragem e a mediação administrativas. ${ }^{68}$

Para se usarem esses meios de resolução de disputas, a negociação entre as partes deve ter sido infrutífera. O Regulamento remete aos procedimentos de arbitragem e de mediação aprovados pela Agência. No entanto, não há procedimentos gerais para qualquer dessas RDs no âmbito da ANATEL: não existe procedimento de mediação aprovado pela Agência e o

ANATEL-ANP. Consulta Pública Conjunta n. 2, de 10 de março de 2000. [on line] Disponível na Internet via WWW. URL: http://www.anatel.gov.br/Tools/frame.asp?link=/acontece_anatel/consulta/2000/cons ulta_002/coment_cp_conjunta_002_2000.pdf (Consultado em 12.07.2006).

${ }^{68}$ Regulamento de Compartilhamento de Infraestrutura entre Prestadoras de Serviço de Telecomunicações, arts. 27 e 28. (BRASIL. Agência Nacional de Telecomunicações. Aprova o Regulamento de Compartilhamento de Infraestrutura entre as Prestadoras dos Serviços de Telecomunicações. Resolução n. 274, de 5 de setembro de 2001). 
procedimento de "arbitragem" existente refere-se à "arbitragem em interconexão", sobre a qual já se discorreu. ${ }^{69}$

Além desses meios de resolução de disputa, também se menciona a arbitragem e a mediação de conflitos entre operadoras pela ANATEL em seu Regimento Interno ${ }^{70}$ e nos contratos de concessão ${ }^{71}$, carecendo da mesma regulamentação. Pelos contratos de concessão, as partes têm a faculdade de submeter à ANATEL, por meio de reunião de composição de

${ }^{69} \mathrm{O}$ art. 45 do Regulamento Geral de Interconexão diz: "Até a expedição de regulamentação específica, eventuais conflitos que possam surgir em matéria de aplicação e interpretação da regulamentação, quando do desenvolvimento das negociações dos contratos de interconexão, devem ser equacionados pela Anatel no exercício da sua função de órgão regulador, conforme prescrito nos arts. $8^{\circ}$ e 19 da Lei n. 9.472, de 1997, por meio do processo de arbitragem definido no Anexo III deste Regulamento". (BRASIL. Agência Nacional de Telecomunicações. Aprova o Regulamento Geral de Interconexão. Resolução n. 410, de 11 de julho de 2005). Intencionalmente ou não, a extensão da aplicação desse processo de arbitragem ainda se limita ao caso de interconexão, não podendo ser considerado universalmente aplicável no âmbito da Agência a qualquer hipótese de arbitragem.

${ }^{70}$ BRASIL. Agência Nacional de Telecomunicações. Aprova o Regimento Interno da Agência Nacional de Telecomunicações, na forma do Anexo a esta Resolução, ficando revogada a Resolução n. 197, de 16 de dezembro de 1999. Resolução n. 270, de 19 de julho de 2001.

${ }^{71}$ BRASIL. Agência Nacional de Telecomunicações. Aprovar os modelos de Contrato de Concessão para a prestação do Serviço Telefônico Fixo Comutado nas modalidades de serviço Local, Longa Distância Nacional (LDN), e Longa Distância Internacional (LDI) e o Plano Geral de Metas de Qualidade para o Serviço Telefônico Fixo Comutado (PGMQ) - 2006. Resolução n. 341, de 20 de junho de 2003. Nos contratos de concessão também é prevista a arbitragem de disputas entre a ANATEL e a concessionária que versem sobre violação do direito da concessionária à proteção de sua situação econômica, sobre revisão das tarifas ou sobre indenizações devidas quando da extinção do contrato, inclusive quanto aos bens revertidos. O estudo sobre a possibilidade de a Agência, pessoa jurídica de direito público, participar de uma arbitragem como parte e a análise de suas implicações sobre a indisponibilidade do interesse público que ela carrega fogem ao escopo deste artigo. De toda sorte, sobre o tema, cf. LEMES, Selma Maria Ferreira. Arbitragem na Concessão de Serviço Público - Perspectivas. In: AZEVEDO, André Gomma de (org.). Estudos em Arbitragem, Mediação e Negociação. Brasília: Brasília Jurídica, 2002, p. 45; e, como parte de uma corrente diferente, ARAÚJO, Helena Caetano de e PIRES, José Cláudio Linhares. Regulação e arbitragem nos setores de serviços públicos no Brasil: problemas e possibilidades. In: Revista de Administração Pública. Vol. 34, n. 5 (set./out. 2000). Rio de Janeiro: Fundação Getúlio Vargas, 2000, p. 9.

Revista de Direito, Estado e Telecomunicações, v. 1, n. 1, p. 111-159 (2009)

DOI: https://doi.org/10.26512/lstr.vli1.21740 
conflitos $^{72}$, de processo de mediação ou de processo de arbitragem, quaisquer conflitos decorrentes da interpretação e da aplicação da regulamentação.

Os processos propriamente gerais de mediação e de arbitragem são previstos no Regimento Interno da Agência e essa previsão constitui a base para a discussão da próxima subseção, merecendo transcrição:

Art. 62. Quando dois ou mais interessados, de comum acordo e por escrito, pretenderem da Agência a solução de pendências relativas ao reconhecimento ou atribuição de direitos, será instaurado procedimento específico de mediação.

$\S 1^{\circ}$ Os interessados serão notificados quanto a data, hora, local e objeto da mediação.

$\S 2^{\circ} 0$ resultado da mediação vinculará as partes perante a Agência.

(...)

Art. 63. Havendo conflito de interesses entre prestadoras de serviços de telecomunicações ou entre estes e os usuários será procedida a arbitragem.

Parágrafo único. As partes, enquanto prestadoras, podem submeter a solução de seus eventuais conflitos ao processo de arbitragem quando houver compromisso prévio de aceitar como vinculante a decisão que vier a ser proferida.

Com esse panorama de atuação da ANATEL na resolução de disputas entre operadoras, pode-se iniciar a investigação do modelo brasileiro a partir da experiência propiciada pelo direito comparado.

\section{Propostas para o modelo brasileiro à luz do direito comparado}

Conforme se demonstrou com o mapeamento feito na subseção anterior, não há um procedimento de arbitragem e um procedimento de mediação regulamentados na ANATEL que sejam amplamente aplicáveis. Assim, tratar-se-á, aqui, de utilização do direito comparado para iluminar a concepção de mediação e de arbitragem que a Agência brasileira carrega e, a partir disso, indicar caminhos possíveis e coerentes com a posição de um órgão regulador frente a um mercado liberalizado.

${ }^{72}$ Não há qualquer previsão regimental para a reunião de composição de conflitos, podendo ser uma espécie de encontro informal entre as partes para se tentar resolver a disputa. Ao que parece, não há qualquer aplicação de técnica mediatária. 


\section{Da competência material}

O primeiro ponto a se discutir é que tipo de disputas poderá o órgão regulador de um país dirimir entre as partes. Quaisquer disputas entre direitos patrimoniais disponíveis? Ou apenas as que forem de competência regulatória da Agência? Neste caso, como separar os casos que podem ser resolvidos pela Agência, por meio da arbitragem e da mediação, dos casos que não o podem?

Dos modelos estrangeiros apresentados, verifica-se que o Japão restringe a atuação da Comissão aos casos de conflitos em interconexão, em compartilhamento de infraestrutura, na negociação de fornecimento de serviços entre prestadoras e, residualmente, a outras disputas cuja resolução seja necessária para a boa prestação de serviços pelas prestadoras.

A regulação nos Estados Unidos permite que, além das obrigações legais das subseções (b) e (c) da Seção 251 do Telecommunications Act ${ }^{73}$, sejam trazidas à mediação ou à arbitragem pela Agência disputas em interconexão e em negociação de serviços e de elementos de rede entre as empresas. A competência da Agência para resolver todas essas disputas demonstra claramente que o objetivo disso é garantir uma justa competição entre os players.

A resolução de disputas pelo Ofcom, na Inglaterra, segue as diretrizes europeias, que, diferentemente da regulamentação americana e japonesa, não trata analiticamente de todos os tipos de disputa que podem ser resolvidos administrativamente pelo órgão. Em vez disso, a regulação apenas informa principiologicamente que a disputa deve ser referente à norma ou diretiva do setor.

O Brasil parece seguir a técnica inglesa para definição de que matérias podem ser dirimidas pela ANATEL. Assim, a mediação deve tratar de "pendências relativas ao reconhecimento ou atribuição de direitos" "74 entre as partes, e a arbitragem, de "conflito de interesses"75 entre operadoras de

${ }^{73} \mathrm{Cf}$. nota 34 supra.

${ }^{74}$ BRASIL. Agência Nacional de Telecomunicações. Aprova o Regimento Interno da Agência Nacional de Telecomunicações, na forma do Anexo a esta Resolução, ficando revogada a Resolução n. 197, de 16 de dezembro de 1999. Resolução n. 270, de 19 de julho de 2001, art. 62 .

${ }^{75}$ BRASIL. Agência Nacional de Telecomunicações. Aprova o Regimento Interno da Agência Nacional de Telecomunicações, na forma do Anexo a esta Resolução, Revista de Direito, Estado e Telecomunicações, v. 1, n. 1, p. 111-159 (2009)

DOI: https://doi.org/10.26512/lstr.vli1.21740 
telecomunicações. É uma forma interessante, pois não se corre o risco de determinado caso demandar a intervenção da Agência e isso não poder ocorrer pela disputa não se enquadrar na listagem taxativa de hipóteses.

Por outro lado, esse tipo de definição também traz problemas. $\mathrm{O}$ principal deles é a possibilidade de desvio de finalidade na atuação da Agência. Uma disputa que não versa propriamente sobre a matéria que é objeto de regulação pela Agência pode passar a ter de ser resolvida por ela. Assim, p. ex., se uma operadora de TV a cabo expõe indevidamente, em uma propaganda sua, a marca de uma operadora de SMP, tem-se, aí, um conflito de interesses, que, em tese, pode ser posto perante a Agência. No entanto, muito dificilmente um conflito como esse prejudicará a concorrência entre as partes a ponto de a Agência precisar intervir.

Dessa forma, a melhor maneira de previsão da atuação da Agência parece mesmo ser a listagem analítica de hipóteses. É importante, no entanto, também deixar a Agência decidir discricionariamente se deve atuar ou não em algum outro caso não contemplado pelo rol de hipóteses, mas que venha a ser potencialmente prejudicial a uma ampla e justa concorrência.

\section{Da autonomia das partes referente à participação na mediação $e$ na arbitragem}

A mediação e a arbitragem na ANATEL são sempre faculdades das partes, que, antes de solicitar a atuação da Agência, têm de entrar em consenso sobre isso. A regulamentação do procedimento no Japão, na Inglaterra $^{76}$ e nos EUA não traz essa necessidade. No modelo americano, esses procedimentos também são facultativos, porém é necessário o requerimento de apenas uma das partes para que se proceda à notificação da outra e ao consequente início do procedimento.

No modelo japonês, a mediação pode ser iniciada com o pedido de apenas uma das partes, porém a arbitragem requer o consenso delas em se submeter ao procedimento. Isso não deixa de ser um traço estranho desse modelo, pois a mediação é um processo autocompositivo; dessa forma, a

ficando revogada a Resolução n. 197, de 16 de dezembro de 1999. Resolução n. 270, de 19 de julho de 2001, art. 63.

${ }^{76}$ No modelo inglês, apesar de o Ofcom não atuar como mediador ou árbitro, existe a possibilidade de, preenchidos os requisitos, ele decidir administrativamente. Para isso, basta que uma das partes pleiteie a sua atuação na disputa.

Revista de Direito, Estado e Telecomunicações, v. 1, n. 1, p. 111-159 (2009)

DOI: https://doi.org/10.26512/lstr.vli1.21740 
colaboração das partes é necessária para que seja eficaz. Quando se admite que apenas uma delas solicite a atuação da Comissão como mediadora, independente da concordância da(s) outra(s), pode-se estar minando o procedimento de resolução de disputa, na medida em que, por mais que haja obrigação legal de cooperação no sentido de se alcançar um resultado, não é isso que conseguirá mudar o animus da parte que não concorda com a atuação da Comissão. Por outro lado, a exigência de consenso para que se proceda à arbitragem pela Comissão, que é um processo heterocompositivo, dá a impressão de que o legislador japonês, quando tratou desses procedimentos, trocou as bolas.

No Regimento Interno da ANATEL, há a exigência de consenso tanto para a instauração da arbitragem pela Agência quanto para o início da mediação. Faz sentido, como se demonstrou, exigir o consenso das partes para que a Agência proceda à mediação. ${ }^{77}$ Já, na arbitragem, exigir o consenso das partes pode significar a necessidade inequívoca de a empresa solicitante ter de ir ao Judiciário, frustrando-se a possibilidade de uma decisão rápida e bem fundamentada ao conflito.

Esse problema foi identificado pelo chamado procedimento de arbitragem em interconexão da ANATEL $^{78}$, porém a arbitragem prevista no Regimento Interno, que rege tudo o mais, não se atentou para isso. Se o conflito tiver implicações concorrenciais perniciosas para a parte solicitante, a Agência deveria, em nome do interesse público, ser capaz de ingressar e dirimir o conflito, como uma espécie de regulação assimétrica. ${ }^{79}$

\footnotetext{
${ }^{77}$ Mesmo que faça sentido exigir o consenso das partes para que se instaure a mediação, há também, por outro lado, vantagens em prescindir desse consenso. Muitas vezes, sendo obrigatória a instauração do procedimento, a parte que estava negando-se a negociar, ao comparecer, pode se sentir mais estimulada a estabelecer uma negociação e conseguir um resultado consensual. A melhor forma parece ser permitir-se à parte requerida na mediação que responda ao requerimento feito pela outra parte perante o órgão regulador, indicando se pretende participar ou não da mediação.

${ }^{78}$ Isso se explica pela natureza ordinariamente administrativa desse procedimento.

${ }^{79}$ Para isso, a noção de contratualidade entre as partes para o procedimento de arbitragem deve ser substituída pela noção de previsão legal. Nos EUA, p.ex., isso ocorre. Pressupõe-se que, quando uma empresa opera no setor de telecomunicações, está aceitando todas as normas que regem o setor, bem como a possibilidade de ser demandada e de demandar em um procedimento arbitral perante o órgão regulador.

Revista de Direito, Estado e Telecomunicações, v. 1, n. 1, p. 111-159 (2009)

DOI: https://doi.org/10.26512/lstr.vli1.21740
} 


\section{Da possibilidade de se escolher o árbitro ou o mediador}

Também como fruto do princípio da autonomia das partes no processo de mediação e arbitragem, é praticamente uma garantia que as partes possam escolher quem será o mediador ou o árbitro da disputa. Isso permite uma maior confiança delas no procedimento e no seu resultado, propiciando, consequentemente, uma regulação mais eficiente, na medida em que é mais difícil que esse resultado seja descumprido por uma das partes.

No Japão, quando uma das partes solicita à Comissão a mediação de um conflito, não se admite qualquer ingerência delas na nomeação ou na indicação do mediador. Diferentemente, quando as partes solicitam a arbitragem, podem indicar, em consenso, quem serão os três árbitros que atuarão, contanto que eles sejam funcionários da Comissão. A Comissão apenas indicará os árbitros se as partes não chegarem a um consenso sobre quem indicar.

Na Dakota do Norte, admite-se a indicação do árbitro e do mediador pelas partes. Em verdade, a Agência dá prioridade à escolha pelas partes. Assim, posteriormente ao requerimento de uma das partes para que ocorra a mediação, ambas deverão entrar em consenso sobre quem será o mediador. Caso não se alcance esse consenso, uma das partes pode requerer à Agência que indique algum funcionário seu para o caso. Esse funcionário fica impedido de atuar na arbitragem ou na homologação do acordo sobre o mesmo caso.

Processo semelhante ocorre na arbitragem. No entanto, as partes não têm plena escolha sobre quem será o árbitro. Devem submeter uma lista à Agência com pelo menos dois árbitros, para que ela escolha um, ou, se não houver consenso, cada uma deve submeter sua própria lista de pessoas que aceita como árbitra. Não ocorrendo qualquer indicação, a própria Agência indica e nomeia um de seus funcionários como árbitro.

$\mathrm{Na}$ Inglaterra, o Ofcom recusa-se a indicar qualquer funcionário para a atuação como árbitro ou mediador em qualquer disputa. Não é sua competência arbitrar ou mediar conflitos, sendo esses procedimentos deixados todos a cargo de instituições e processos privados. Se essas formas de resolução forem ineficazes, aí sim o órgão decidirá. No entanto isso se dá por um procedimento decisório administrativo tipicamente discricionário.

Nesse aspecto de indicação de árbitros e de mediadores, os três países demonstram experiências bem diferentes um do outro. Na regulamentação 
da ANATEL, não há qualquer menção à possibilidade de indicação de um mediador ou árbitro privado, na medida em que a Agência enxerga a arbitragem e a mediação que pratica sob um prisma de direito privado, isto é, assim como as partes podem recorrer a um árbitro ou a um mediador privado, podem recorrer à Agência se quiserem.

A participação de uma pessoa da Agência na decisão de uma disputa entre operadoras de telecomunicações é uma questão delicada. Isso porque, em princípio, apesar do princípio da confidencialidade, nada garante que as informações apreendidas pelo funcionário que se envolve na disputa não serão usadas contra a(s) parte(s) futuramente pela Agência. Por esse motivo, recomenda-se que o funcionário que participe da resolução da disputa fique impedido de atuar, ao menos, em procedimentos futuros relacionados a esse caso.

Além disso, alguns duvidam da imparcialidade da Agência em conduzir uma mediação, na medida em que ela está vinculada ao interesse público. ${ }^{80}$ Esse parece ser um óbice falacioso, na medida em que a atuação da Agência na resolução das disputas dá-se exatamente por força do interesse público (proteção da concorrência). Assim, a defesa do interesse público dá-se pela mera colaboração da Agência (como mediadora ou árbitra) na pacificação do conflito, e não na orientação do resultado da disputa a algum fim escuso.

\section{Da liberdade de procedimento}

Também se afere o grau de autonomia das partes em uma RD pela liberdade que possuem de acordarem os procedimentos a serem seguidos. Os procedimentos de mediação e arbitragem em disputas resolvidas pelo órgão regulador são dispostos em lei ou regulamento. No entanto, muitas vezes esse procedimento não é imperativo, isto é, as partes podem decidir

80“(...) it might be argued that the commission cannot participate in mediation because it must always function in a manner that enhances the public interest. Yet the Telecommunications Act clearly allows commissions to participate in the negotiation and mediation of differences between private parties". (BURNS, Robert E., DAVIS, Vivian Witkind e WIRICK, David W. Some issues in commission mediation and arbitration of interconnection agreements: defining and staffing the administrative process. Columbus, Ohio: The National Regulatory Research Institute, 1996. [on line] Disponível na Internet via WWW. URL: http://www.nrri.ohio-state.edu/dspace/bitstream/2068/235/1/96-17.pdf (Consultado em 30.06.2006).

Revista de Direito, Estado e Telecomunicações, v. 1, n. 1, p. 111-159 (2009)

DOI: https://doi.org/10.26512/lstr.vli1.21740 
por um outro caminho para a resolução da disputa sem suprimir a natureza e os aspectos essenciais da forma de RD utilizada.

Assim, é com a abertura que o regulamento ou a lei dá que se pode avaliar até que ponto a liberdade das partes em construir o processo é preservada. A possibilidade de as partes fazerem-no permite o tratamento necessário de acordo com a complexidade da disputa - disputas mais complexas necessitam de mais tempo, para convocação de peritos e realização de análises - e conforme a disponibilidade de tempo das partes em colaborar com o andamento da arbitragem ou da mediação.

No Japão, como se observou, há pouco espaço para as partes criarem ou negociarem o procedimento a ser seguido, tanto na mediação quanto na arbitragem. Esse controle sobre o processo limita-se praticamente à realização de audiências, que as partes escolhem quando e quantas serão. Pode-se considerar também uma liberdade das partes o fato de poderem reapresentar suas alegações à medida que as audiências vão prosseguindo.

Fora esses aspectos, as partes não têm qualquer autonomia sobre, p. ex., a decisão do árbitro ou sobre quem - além delas - pode estar presente à mediação. O processo de arbitragem é sigiloso, mas a Comissão pode decidir disponibilizar ao público determinadas informações, independentemente da concordância das partes. Além desses, há uma miríade de outros fatores nodais que poderiam ter sido afrouxados em favor de uma maior autonomia das partes sobre o processo. No entanto, a sua rigidez demonstra bem a natureza administrativa dos procedimentos de mediação e de arbitragem na Comissão de Resolução de Disputas Comerciais em Telecomunicações japonesa.

A liberdade sobre o processo no modelo inglês é praticamente inexistente, pois o Ofcom declaradamente não atua como mediador ou como árbitro, deixando esses procedimentos a cargo do meio privado buscado pelas próprias partes. Assim, o processo de resolução de disputas do órgão regulador inglês é um processo administrativo (ou melhor, quase-judicial, como se verá mais claramente no próximo item) de decisão. Há, no entanto, pelo menos uma vantagem em relação ao modelo japonês: se as partes requererem a confidencialidade de determinadas informações, o órgão regulador inglês não pode decidir pelo contrário e publicá-las.

Das experiências estrangeiras observadas, a americana é a que abre uma maior liberdade sobre $\mathrm{o}$ procedimento às partes em disputa. A 
regulamentação da mediação do estado da Dakota do Norte, por exemplo, estabelece que a sessão é totalmente confidencial. Afora esse ponto, a mediação não apresenta muitos aspectos inovadores quanto à liberdade de procedimento, pois é um mecanismo naturalmente autocompositivo. É no procedimento de arbitragem que se enxerga uma maior flexibilidade relativa.

Apesar da exigência de as partes serem representadas por seus advogados, a regulamentação da arbitragem pela public service commission da Dakota do Norte permite que as partes, em consenso, imponham condições ao processo, estabeleçam as etapas de cumprimento do acordo e decidam sobre a ocorrência de audiências para oitiva de testemunhas. As partes também podem continuar a negociação mesmo depois de feitas as ofertas finais, o que contribui para a legitimidade da decisão, na medida em que há um teor autocompositivo maior. Para reforçar isso, ainda se permite a elas restringir o escopo de decisão do árbitro, estabelecendo, p. ex., um limite mínimo e outro máximo dentro dos quais o árbitro deve decidir o valor de uma tarifa de interconexão.

É importante que, além de a mediação carregar a autocomposição, a arbitragem também possua aspectos autocompositivos, por mais que estes não tanjam diretamente ao resultado da disputa, mas ao procedimento. Assim, garantir uma voz às partes tanto no procedimento quanto na autonomia decisória do árbitro contribui para a legitimidade do processo e para uma visão, pelas partes, de que o que ocorreu - o processo e o resultado - foi justo. ${ }^{81}$

81“"Pesquisadores mais antigos da área processual, notadamente John Thibaut e Laurens Walker, sustentavam que as partes valorizavam o controle sobre o processo principalmente porque isso lhes permitia alcançar resultados substanciais. (...) Pesquisadores mais recentes no âmbito processual e procedimental, como E. Allan Lind e Tom Lyer, em contraste, sustentam que o controle sobre o processo é valorizado principalmente porque dá às partes uma chance de ter uma voz e participar significativamente no processo. De acordo com essa visão intrínseca ou 'orientada para o procedimento' do controle processual, 'a mera experiência de uma oportunidade para expressar-se será vista como justa - não há referência ao resultado do procedimento"". (GUTHRIE, Chris e LEVIN, James. A "Party Satisfaction" Perspective on a Comprehensive Mediation Statute. In: Ohio State Journal on Dispute Resolution. Ohio, vol. 13, 1998. p. 887. Tradução livre do original).

Revista de Direito, Estado e Telecomunicações, v. 1, n. 1, p. 111-159 (2009)

DOI: https://doi.org/10.26512/lstr.vli1.21740 


\section{Da possibilidade de recursos}

Pode-se dizer, com certo grau de radicalismo, porém ainda de forma realista, que um método de resolução de disputas é inútil se permite uma rediscussão da matéria no Poder Judiciário. De fato, o objetivo das RDs é terminar o conflito. Se há possibilidade de revisão por um tribunal, ou o conflito não foi resolvido - as partes não se empenharam no método de RD por saber que existia a possibilidade de uma discussão no Judiciário -, ou a parte que propôs a discussão judicial da causa está agindo de má-fé. Para evitar essas duas situações, o mais coerente parece ser negar a atuação do Poder Judiciário no mérito das questões resolvidas em RDs. ${ }^{82}$

No Japão, a decisão da Comissão de Resolução de Disputas em Telecomunicações em um processo de arbitragem não se submete a qualquer recurso interno. Não há, no entanto, nenhuma restrição expressa indicando a incompetência dos tribunais em revisar a deliberação da Comissão. A decisão é, portanto, próxima da decisão de um processo administrativo.

$\mathrm{Na}$ Inglaterra se tem uma situação assaz singular. Nas resoluções das disputas submetidas ao Ofcom - o que não ocorre por meio de arbitragem ou de mediação, mas por um procedimento próprio -, ele não dispõe de recursos internos para revisão da decisão, mas possibilita o recurso ao Poder Judiciário. Assim, há uma simbiose entre o Ofcom e o Poder Judiciário, na medida em que aquele já se situa como um primeiro grau de jurisdição, ou seja, a decisão do Ofcom pode ser considerada quase-judicial. O tribunal que receber a "apelação" pode revisar o mérito da decisão, porém da decisão desse tribunal só cabe recurso de natureza extraordinária, isto é, que permite apenas a re-análise de questões de direito, não de fatos.

Na Dakota do Norte - e nos Estados Unidos em geral -, não cabe qualquer recurso no âmbito da agência que decide a disputa. Há ainda uma disposição no Telecommunications Act que proíbe qualquer tribunal estadual

${ }^{82}$ Essa pontuação aplica-se mais propriamente à arbitragem, na medida em que a natureza do acordo fruto da mediação é contratual. Dessa forma, feito o contrato, não cabe qualquer questionamento sobre as obrigações nele contidas, a não ser de questões que versem sobre a nulidade do instrumento. No Brasil, p. ex., a Lei de Arbitragem permite que o Judiciário manifeste-se apenas extrinsecamente sobre a sentença arbitral, apontando eventual nulidade caso ela não contenha os requisitos objetivos previstos em lei.

Revista de Direito, Estado e Telecomunicações, v. 1, n. 1, p. 111-159 (2009) 
de imiscuir-se na decisão ${ }^{83}$ Assim, conclui-se que a única ação revisional sobre essa decisão concerne à revisão do procedimento de arbitragem ou de mediação, submetida ao Poder Judiciário federal e fundado no descumprimento das disposições da lei. Essa determinação pode parecer autoritária, mas não o é de fato, principalmente se observada à luz das liberdades de procedimento conferidas às partes no processo de arbitragem das agências americanas e da restrição imposta à autonomia decisória do árbitro, que deve decidir por meio da técnica de oferta final.

No Brasil, da decisão da ANATEL no procedimento de "arbitragem" em interconexão cabe uma série de recursos, o que vem a salientar o caráter administrativo dessa decisão. Em princípio, é possível recurso para o Conselho Diretor da Agência. ${ }^{84}$ A decisão do Conselho Diretor, por sua vez, pode submeter-se a uma reavaliação no Poder Judiciário típica a qualquer ato administrativo comum, sendo atacada por um processo de duplo grau de jurisdição, além de instâncias extraordinárias.

O procedimento de resolução de conflitos aprovado pela Resolução Conjunta ANEEL-ANATEL-ANP n. 2/2001 também prevê um pedido de reconsideração, podendo ser igualmente objeto de discussão judicial. Já a arbitragem do Regimento Interno da Agência, por falta de regulamentação, não esclarece se permite uma revisão de mérito da decisão.

$O$ ideal parece ser a revisão judicial apenas no que se refere ao descumprimento de princípios legais e procedimentais pela Agência, não se devendo controlar outros aspectos de sua decisão. Nesse sentido, é importante que o Judiciário não atue reformando a decisão, mas anulando-a, em hipóteses próximas às dispostas na Lei de Arbitragem brasileira. ${ }^{85}$

${ }^{83}$ Cf. nota 43 supra.

${ }^{84}$ BRASIL. Agência Nacional de Telecomunicações. Aprova o Regulamento Geral de Interconexão. Resolução n. 410, de 11 de julho de 2005, Anexo III. Art. 20.

${ }^{85}$ Estabelece a Lei de Arbitragem:

"Art. 32. É nula a sentença arbitral se:

I - for nulo o compromisso;

II - emanou de quem não podia ser árbitro;

III - não contiver os requisitos do artigo 26 desta Lei;

IV - for proferida fora dos limites da convenção de arbitragem;

$\mathrm{V}$ - não decidir todo o litígio submetido à arbitragem;

VI - comprovado que foi proferida por prevaricação, concussão ou corrupção passiva;

Revista de Direito, Estado e Telecomunicações, v. 1, n. 1, p. 111-159 (2009)

DOI: https://doi.org/10.26512/lstr.vli1.21740 


\section{Conclusão}

A maioria das hipóteses em que a ANATEL resolve conflitos entre operadoras trata-se de processo administrativo. O único momento em que se pode afirmar que há possibilidade de ocorrência efetiva de mediação ou de arbitragem é quanto às disposições em seu Regimento Interno. No entanto, a falta de regulamentação - principalmente da arbitragem - elimina os trunfos que esse tipo de procedimento conduzido por um órgão regulador poderia ter.

Pode-se dizer que as duas grandes vantagens da realização da arbitragem e da mediação por uma instituição regulatória oficial são a possibilidade de se iniciar o processo sem uma concordância prévia da outra parte e a restrição dada à revisão da decisão pelo Poder Judiciário. Esses fatores colaboram para que a decisão definitiva da causa ocorra de maneira célere, contemplando, assim, o interesse público de proteção da concorrência entre as operadoras.

Adotar essas medidas não se trata de cerceamento de defesa, pois, como visto na seção anterior, há várias liberdades no procedimento que compensam essa decisão "em única instância" da arbitragem e da mediação. Principalmente na arbitragem, é salutar balancear essas medidas com, p. ex., a possibilidade de as partes escolherem os árbitros, elaborarem o procedimento conjuntamente com o árbitro e restringirem a autonomia decisória deste, o que pode ocorrer pelo próprio regulamento do procedimento de arbitragem, que pode prever que o árbitro se atenha à arbitragem de oferta final ou a uma de suas variações, de forma a garantir uma maior legitimidade da decisão.

A criação de procedimentos de arbitragem e de mediação mais eficazes e fiéis é uma necessidade cuja satisfação depende de grande vontade política e - mormente no caso da mediação - de recursos humanos bem preparados para isso. Isso parece ter sido captado pela ANATEL, que talvez crie, em

VII - proferida fora do prazo, respeitado o disposto no artigo 12, inciso III, desta Lei; e

VIII - forem desrespeitados os princípios de que trata o artigo $21, \S 2^{\circ}$, desta Lei". 
sua reforma estrutural, uma área especializada em composição de conflitos entre prestadoras de serviços de telecomunicações. ${ }^{86}$

No entanto, a partir da leitura da atuação da agência brasileira, comparando-a com outros países, vê-se a necessidade de uma previsão em lei da realização da arbitragem. ${ }^{87}$ Caso contrário, a ANATEL deverá submeter-se à Lei de Arbitragem ordinária. ${ }^{88}$ Em suma, sem uma previsão legal específica para a prática da arbitragem pela Agência, os dois trunfos apontados linhas acima não podem efetivar-se.

Portanto, o procedimento de arbitragem privada comum tem pressupostos distintos da arbitragem conduzida por um órgão regulador, e, para que se façam efetivamente presentes esses pressupostos, precisa-se ter um procedimento diferenciado, porém ainda fiel aos aspectos essenciais de uma arbitragem, conforme exposto neste artigo. É verdade que essa necessidade de um procedimento próprio, especial, não ocorre tanto com a mediação praticada pelo órgão regulador. ${ }^{89} \mathrm{Em}$ contrapartida, o investimento público que se tem de fazer para se formar um bom mediador é maior que o investimento feito para se ter um bom árbitro. $\mathrm{O}$ resultado da mediação é, por outro lado, mais legítimo que o da arbitragem.

${ }^{86}$ É o que se nota da leitura do último Regimento Interno da Agência, aprovado pela Resolução n. 415/2005, mas cuja publicação no DOU (em 11/10/2005) foi tornada ineficaz pelo Ato do Conselho Diretor da ẢNATEL n. 53.660/2005:

"Art. 174 A Superintendência de Relações com Prestadoras é constituída pelos seguintes órgãos fracionários:

I- Gerência de Acompanhamento de Contratos entre Prestadoras;

II- Gerência de Composição de Conflitos; e

III- Gerência de Acompanhamento Societário e da Ordem Econômica."

${ }^{87} \mathrm{~A}$ única disposição legal que possibilita à ANATEL atuar genericamente na resolução de disputas entre operadoras é o inc. XVII do art. 19 da LGT, que aponta a competência da Agência de "compor administrativamente conflitos de interesses entre prestadoras de serviço de telecomunicações" [grifo ausente no original].

${ }^{88}$ Alguns defendem que a ANATEL não pode sequer atuar como árbitra nos termos da Lei n. 9.307/1996. No entanto, fazer essa restrição é depauperar ainda mais a capacidade de a Agência resolver disputas entre os agentes do setor. Além disso, se à ANATEL é permitido ser parte em uma arbitragem civil, não parecem restar motivos que a impeçam de atuar como árbitra, se for escolhida por consenso das partes e se a resolução da disputa for de interesse público.

${ }^{89} \mathrm{~A}$ característica de autocomposição dessa RD elimina maiores questionamentos sobre o cerceamento de defesa das partes ou de previsão legal do procedimento.

Revista de Direito, Estado e Telecomunicações, v. 1, n. 1, p. 111-159 (2009)

DOI: https://doi.org/10.26512/lstr.vli1.21740 
Como se vê, a arbitragem e a mediação são duas formas distintas e complementares de resolução de disputas. Um órgão regulador de telecomunicações deve praticar com eficiência essas duas RDs perante um mercado liberalizado, de sorte a permitir que os conflitos entre as operadoras causem o menor dano possível à concorrência entre as empresas, o que se consegue por meio de uma resolução definitiva, rápida e legítima das disputas.

\section{Bibliografia}

\section{Obras e publicações}

ALMEIDA, Fábio Portela Lopes de. A teoria dos jogos: uma fundamentação teórica dos métodos de resolução de disputa. In: AZEVEDO, André Gomma de (org.). Estudos em Arbitragem, Mediação e Negociação. Vol. 2. Brasília: Grupos de Pesquisa, 2003.

ARANHA, Márcio Iorio (org.). Coletânea Brasileira de Normas e Julgados de Telecomunicações e Glossário Brasileiro de Direito das Telecomunicações. São Paulo: Quartier Latin, 2006.

ARAÚJO, Helena Caetano de e PIRES, José Cláudio Linhares. Regulação e arbitragem nos setores de serviços públicos no Brasil: problemas e possibilidades. In: Revista de Administração Pública. Vol. 34, n. 5 (set./out. 2000). Rio de Janeiro: Fundação Getúlio Vargas, 2000.

BRUCE, Robert R. [et alii]. Dispute Resolution in the Telecommunications Sector: Current Practices and Future Directions. Genebra: União Internacional de Telecomunicações/Banco Mundial, 2003. [on line] Disponível na Internet via WWW. URL: http://www.itu.int/ITUD/treg/Events/ Seminars/2003/GSR/Documents/DRS_Final_GSR_5.pdf (Consultado em 30.06.2006).

BURNS, Robert E., DAVIS, Vivian Witkind e WIRICK, David W. Some issues in commission mediation and arbitration of interconnection agreements: defining and staffing the administrative process. Columbus, Ohio: The National Regulatory Research Institute, 1996. [on line] Disponível na Internet via WWW. URL: http://www.nrri.ohiostate.edu/dspace/bitstream/2068/235/1/96-17.pdf (Consultado em 30.06.2006). 
CARMONA, Carlos Alberto. Arbitragem e processo: um comentário à Lei n. 9.307/96. $2^{\mathrm{a}}$ ed. São Paulo: Atlas, 2004.

COSTA, Henrique Araújo. Resolução alternativa de conflitos no setor elétrico nacional. In: AZEVEDO, André Gomma de (org.). Estudos em Arbitragem, Mediação e Negociação. Vol. 2. Brasília: Grupos de Pesquisa, 2003.

EUROPEAN TELECOMMUNICATIONS PLATFORM. Inventory of Dispute Resolution Mechanisms: What are the choices for the telecommunications sector? Bruxelas: The European Union On-Line. [on line] Disponível na Internet via WWW. URL: http://europa.eu.int/ISPO/infosoc/telecompolicy/en/dispute.pdf (Consultado em 30.06.2006).

GT ARBITRAGEM. Glossário: métodos de resolução de disputas - RDs. In: AZEVEDO, André Gomma de (org.). Estudos em Arbitragem, Mediação e Negociação. Vol. 3. Brasília: Grupos de Pesquisa, 2004.

GUTHRIE, Chris e LEVIN, James. A "Party Satisfaction" Perspective on a Comprehensive Mediation Statute. In: Ohio State Journal on Dispute Resolution. Ohio, vol. 13, 1998.

HILL, Richard. Dispute Resolution in Telecommunications. Genebra: WWW Multimedia Law. [on line] Disponível na Internet via WWW. URL: http://www.oikoumene.com/arblaw.html (Consultado em 30.06.2006).

JAPÃO. Ministry of Internal Affairs and Communications. What is the Telecommunications Business Dispute Settlement Commission? Tóquio: Ministry of Internal Affairs and Communications. [on line] Disponível na Internet via WWW. URL: http://www.soumu.go.jp/hunso/english/tbdc.html (Consultado em 13.07.2006).

Ministry of Public Management, Home Affaires, Posts and Telecommunications. International Affairs Department. International Cooperation Division. Interconnection rules. Bangkok: Asia Pacific Telecommunity. [on line] Disponível na Internet via WWW. URL: http://www.aptsec.org/meetings/2004/PRF/documents/INF05-

Interconnection-JPN.ppt (Consultado em 13.07.2006).

JONES, Colin P. A. Japan's Telecommunications Business Dispute Resolution Committee. Londres: BNA International. [on line] Disponível 
na Internet via WWW. URL: http://www.lw.com/resource/publications/_pdf/pub729.pdf (Consultado em 30.06.2006).

LAENDER, Gabriel Boavista. Interconexão, unbundling $e$ compartilhamento de meios de redes de telecomunicação. In: Revista de Informação Legislativa, Brasília, ano 39, n. 154, p. 41-49, abr./jun. 2002. LEMES, Selma Maria Ferreira. Arbitragem na Concessão de Serviço Público - Perspectivas. In: AZEVEDO, André Gomma de (org.). Estudos em Arbitragem, Mediação e Negociação. Brasília: Brasília Jurídica, 2002.

Arbitragem na Concessão de Serviços Públicos - Arbitrabilidade

Objetiva. Confidencialidade ou Publicidade Processual? Brasília: Confederação das Associações Comerciais e Empresariais do Brasil. [on line] Disponível na Internet via WWW. URL: http://www.cacb.org.br/mediacao_arbitragem/artigos/ (Consultado em 30.06.2006).

LUHMANN, Niklas. El derecho de la sociedad. Tradução de Javier Torres Nafarrate. México, 1999. Manuscrito.

OLIVEIRA, Artur Coimbra de. Para a verificação da eficácia de uma mediação transformadora. In: AZEVEDO, André Gomma (Org.). Estudos em Arbitragem, Mediação e Negociação. Vol. 4. Brasília: Grupos de Pesquisa, 2006. No prelo.

OTTOW, Annetje. Dispute resolution under the new European framework. Amsterdã: Faculteit der Rechtsgeleerdheid, Universiteit van Amsterdam, 2003. [on line] Disponível na Internet via WWW. URL: http://www.ivir.nl/publicaties/ottow/disputeresolutionundertheneweuframe work.PDF (Consultado em 30.06.2006).

REZIO, Juliana Oliveira. Resolução de Conflitos em Compartilhamento de Infra-Estrutura. In: Revista Teletime, Ano 5, n. 41, fevereiro de 2002.

RISKIN, Leonard L. Compreendendo as orientações, estratégias e técnicas do mediador: um padrão para iniciantes. Tradução de Henrique Araújo Costa. In: AZEVEDO, André Gomma (Org.). Estudos em Arbitragem, Mediação e Negociação. Brasília: Brasília Jurídica, 2002.

TODOROV, Francisco Ribeiro. Concorrência em telecomunicações. Brasília, 2003. Manuscrito. 


\section{Instrumentos normativos}

BRASIL. Lei n. 9.307, de 23 de setembro de 1996. Dispõe sobre a arbitragem.

. Lei n. 9.427, de 26 de dezembro de 1996. Institui a Agência Nacional de Energia Elétrica - ANEEL, disciplina o regime das concessões de serviços públicos de energia elétrica e dá outras providências.

. Lei n. 9.472, de 16 de julho de 1997. Dispõe sobre a organização dos serviços de telecomunicações, a criação e funcionamento de um órgão regulador e outros aspectos institucionais, nos termos da Emenda Constitucional n. 8, de 1995.

- Agência Nacional de Telecomunicações. Aprova o Regimento Interno da Agência Nacional de Telecomunicações, na forma do Anexo a esta Resolução, ficando revogada a Resolução n. 197, de 16 de dezembro de 1999. Resolução n. 270, de 19 de julho de 2001.

- Aprova o Regulamento de Compartilhamento de Infra-

estrutura entre as Prestadoras dos Serviços de Telecomunicações. Resolução n. 274, de 5 de setembro de 2001

- Aprovar os modelos de Contrato de Concessão para a prestação do Serviço Telefônico Fixo Comutado nas modalidades de serviço Local, Longa Distância Nacional (LDN), e Longa Distância Internacional (LDI) e o Plano Geral de Metas de Qualidade para o Serviço Telefônico Fixo Comutado (PGMQ) - 2006. Resolução n. 341, de 20 de junho de 2003.

n. 410 , de 11 de julho de 2005 .

Aprova o Regulamento Geral de Interconexão. Resolução Aprova o Regimento Interno da Agência Nacional de Telecomunicações - Anatel. Resolução n. 415, de 10 de outubro de 2005. . Torna sem efeito a publicação da Resolução n. 415. Ato do Conselho Diretor n. 53.660, de 20 de outubro de 2005. ANEEL-ANATEL-ANP. Consulta Pública Conjunta n. 2, de 10 de março de 2000. [on line] Disponível na Internet via WWW. URL: http://www.anatel.gov.br/Tools/frame.asp?link=/acontece_anatel/consulta/ 2000/consulta_002/coment_cp_conjunta_002_2000.pdf (Consultado em 12.07.2006). 
Aprova o Regulamento Conjunto para Compartilhamento de Infra-estrutura entre os Setores de Energia Elétrica, Telecomunicações e Petróleo. Resolução Conjunta n. 1, de 24 de novembro de 1999.

Aprova o Regulamento Conjunto de Resolução de Conflitos das Agências Reguladoras dos Setores de Energia Elétrica, Telecomunicações e Petróleo. Resolução Conjunta n. 2, de 27 de março de 2001.

. Câmara dos Deputados. Projeto de Lei n. 4.827, de 1998.

. Ministério das Comunicações. Exposição de Motivos n. 231/MC (Lei Geral de Telecomunicações), de 10 de dezembro de 1996.

DAKOTA DO NORTE. Article 69-02: Practice and Procedure. Chapter 6902-10: Arbitration. [on line] Disponível na Internet via WWW. URL: http://www.legis.nd.gov/information/acdata/html/69-02.html (Consultado em 18.04.2006).

Article 69-02: Practice and Procedure. Chapter 69-02-11: Mediation. [on line] Disponível na Internet via WWW. URL: http://www.legis.nd.gov/information/acdata/html/69-02.html (Consultado em 18.04.2006).

ESTADOS UNIDOS DA AMÉRICA. Telecommunications Act. Disponível na Internet via WWW. URL: http://www.fcc.gov/Reports/tcom1996.txt (Consultado em 16.10.2006).

INGLATERRA. Communications Act 2003. Disponível na Internet via WWW. URL: http://www.communicationsact.gov.uk/ (Consultado em 13.07.2006).

JAPÃO. Lei Comercial de Telecomunicações. [on line] Disponível na Internet via WWW. URL: http://www.soumu.go.jp/joho_tsusin/eng/Resources/laws/2001TBL.pdf (Consultado em 13.07.2006).

UNIÃO EUROPEIA. Diretiva 2002/21/EC, de 7 de março de 2002. [on line] Disponível na Internet via WWW. URL: http://europa.eu/scadplus/leg/en/lvb/124216a.htm (Consultado em 13.07.2006). 
